Portland State University

PDXScholar

1975

\title{
Social Workers' Attitudes About Poverty
}

Trudy Hussmann

Portland State University

Follow this and additional works at: https://pdxscholar.library.pdx.edu/open_access_etds

Part of the Social Work Commons Let us know how access to this document benefits you.

\section{Recommended Citation}

Hussmann, Trudy, "Social Workers' Attitudes About Poverty" (1975). Dissertations and Theses. Paper 1839.

https://doi.org/10.15760/etd.1838

This Thesis is brought to you for free and open access. It has been accepted for inclusion in Dissertations and Theses by an authorized administrator of PDXScholar. Please contact us if we can make this document more accessible: pdxscholar@pdx.edu. 
SOCIAL WORKERS'

ATTITUDES ABOUT POVERTY

by

TRUDY HUSSMANN

A practicum submitted in partial fulfillment of the requirements for the degree of

MASTER OF SOCIAL WORK

Portland State University

1976 
The advisor approved this practicum presented May 26, 1976.

John Longres, Advisor 
TABLE OF CONTENTS

PAGE

LIST OF TABLES ........................ iv

CHAPTER

I INTRODUCTION AND THEORETICAL FRAMEWORK . . I

II REVIEW OF THE LITERATURE . . . . . . . . . 7

III RESEARCH DESTGN AND METHODOLOGY. . . . . . . 17

IV RESULTS, CONCLUSIONS, AND LIMITATIONS . . . 26

V SUMMARY AND RECOMMENDATIONS . . . . . . 55

BIBLIOGRAPHY. . . . . . . . . . . . . . 61

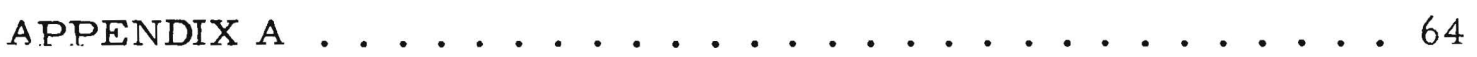

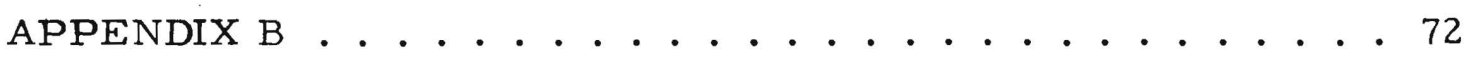




\section{LIST OF TABLES}

TABLE

PAGE

I Factor Analysis--Part I............ 28

II Factor Analysis--Part II

(Direct Service).............. 30

III Percentage of Agrees, Disagrees

and Non-Responses............ 33

IV Mean No. of "Agrees" per Category

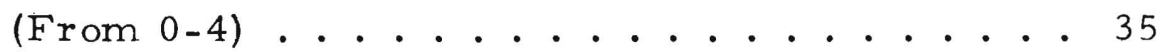

V Comparison of Agreements With

Paradigm I and Paradigm II Statements. . . . 36

VI Comparison of Agreements With Liberal

and Conservative and Radical Statements . . . 39

VII Items With High Agreement Rate . . . . . . . . 40

VIII Items With High Disagreement Rate. . . . . . . 45 


\section{CHAPTER I}

\section{INTRODUCTION \\ AND}

THEORETICAL FRAMEWORK

This study grew out of my own interest in seeking to understand the causes of social problems as a prerequisite to envisioning adequate solutions. Through reading and lectures I began to come to my own conclusions. I was also aware that, as a professional social worker, I would find myself working together with other workers holding varying points of view on such issues. I wondered what this range of views would be; whether there was a general trend, and how the ideologies of practicing social workers might influence the course of social problems. As a way to satisfy some of my curiosity and interest, I decided to do a research project studying the attitudes of social workers in the Portland area around one specific social problem; namely, poverty--to find out what they saw as causes and possible solutions.

Hence, the purpose of this study is to assess the attitudes of a select group of social workers in the Portland area. The study will focus on their attitudes about the causes of poverty and actions to deal with problems of poverty. These attitudes will be examined in the context of a theoretical framework.

The sample consists of those social workers and social workrelated professionals who serve as field instructors for the Portland State School of Social Work. This means that the study will al so provide information about the attitudes that Portland State social work 
students are likely to encounter in the field during the master's program. This information may be useful to the school in evaluating, developing, or modifying curriculum.

The theoretical framework used here is based on the work of Roland Warren. Warren develops two theoretical paradigms which he believes guide social work practice. Following Kuhn, he defines paradigm to be that

which carries the "explanation" for why certain people are poor or disadvantaged, and in so doing implies the way poverty will be conceptualized as a problem, what strategies will be utilized to deal with it, what technologies will be required, and what aspects of the total situation surrounding poverty will be singled out as highly significant, and what aspects will be left as unimportant or irrelevant.

Warren delineates two distinct paradigms or contexts in which to understand social problems. Paradigm I as sumes that the institutions of society are basically sound. Within this framework, the democratic pluralism of interest groups is seen as the process through which social needs are met. If social or human services are inadequate, organizational reform (i.e., of the welfare system) is called for. The principle of inducements is used to encourage existing organizations to take on new or added responsibilities in providing services; i.e., through special grants. Scientific progress is utilized to help solve the human problems which persist in spite of or because of technological advances.

Within this paradigm, the concept of a residual "problem population" (the poor, the delinquent, etc.) is accepted. There are some people who just don't make it, and if they don't it's their own

${ }^{1}$ Roland Warren, "The Sociology of Knowledge and the Problems of the Inner Cities," Social Science Quarterly, 52; No. 3 (Dec. 1971), 469-492. 
fault because everyone basically has the same rights and opportunities. This principle, which grows out of our heritage of "rugged individualism," also applies to minority or special interest groups within the population. If they don't organize to press for their needs, it's their fault, too, because they certainly have the right to do so.

Critics of the system tend to be tolerated as long as they don't have the power to seriously threaten the prevailing order of ideas and institutions. Protestors are often criticized for their lack of ability to present viable alternatives, the enormity of this task sometimes being discounted. Dissenters tend to be viewed as somehow deviant and, depending on their degree of nonconformity, they may be seen as sick individuals in need of psychotherapy.

Paradigm II maintains that the causes of social problems lie within the structure of society and its institutions, and that structural, not individual change is necessary to solve these problems. This is in direct opposition to the Paradigm I assumption that the existing social institutions are basically sound. Within Paradigm II, individual "deficiencies" are seen as being systematically produced by structural inadequacies, rather than springing from inherent defects of individuals themselves. For example, a high rate of illegitimate births is sometimes named as a problem of young, black, poor women. The implication is that the moral standards of these women are defective and, therefore, they engage in sexual promiscuity, resulting in illegitimate births. From a Paradigm II perspective, it could be argued that their moral standards are not significantly different from those of white middle-class women. Instead, poor black women may 
have more illegitimate children because their chances of marriage in reaction to an out-of-wedlock pregnancy are smaller. White women are often rescued from the dilemma precisely this way--the boyfriend or fiance who fathered the child capitulates to a premature wedding. However, because of high unemployment rates among young black males, due to discrimination and institutionalized racism, the young black woman who is pregnant out of wedlock is less likely to be involved with a man able to marry and support her. Hence, she may be more likely to have an illegitimate child, all questions of morality a side.

Whereas Paradigm I is supported by dominant American values such as "materialistic individualism, " 2 liberalism, individual freedom, competition, and the right to private property, the belief-value system supporting Paradigm II remains somewhat vague. Paradigm I values have been incorporated into the institutional foundations of our society. The more humanistic values of Paradigm II comprise a theoretical alternative to the institutionalized values of Paradigm I. "Putting people before profits" is an ideal espoused by some liberals and radicals which is not yet manifested in the workings of our society. Paradigm II al so has a problem with creating clear administrative and technological alternatives--no one has yet envisioned an adequate way to replace bureaucracy. Questions of "transfer of power" and redistribution of income have been grappled with, but no feasible and acceptable solutions have been found.

2 Dorothy Buckton James, "Reflection of American Values in Attitudes and Procedures of the Professions, "Poverty, Politics, and Change (Englewood Cliffs, N. J.: Prentice-Hall, 1972), pp. 72-103. 
Within a Paradigm II social system, the application of social and scientific research would be accountable to the clients served; power issues would be critical, and tasks at hand merely "problematical." Organizations and ideas might be truly competitive, rather than all colluding in the maintenance of an institutionalized and entrenched value system.

The foregoing briefly explains the distinction between Warren's Paradigms $I$ and II, the main premises being that the former tends to see social problems as originating in deficient individuals or groups, and the latter in the structure and functioning of our social institutions. Likewise, Paradigm I sees the solutions to social problems lying chiefly in the rehabilitation of inadequate individuals or groups, whereas Paradigm II sees the solutions in the restructuring of our major social institutions, including shifts in the balance of power, redistribution of income, etc. The implication is that a Paradigm I perspective, while patching up problems and treating symptoms, does nothing to change the basic causal factors; hence, the problems will recur and persist, and the system will perpetuate itself in spite of ups and downs.

The study reported here is an attempt to assess where the beliefs and attitudes of a sample of local social workers lie along the continu um from Paradigm I to Paradigm II. Their attitudes are examined specifically in relationship to the social condition of poverty. It is an effort to shed some light on the following: Do social workers basically, though perhaps unintentionally, support our dominant belief-value system (and hence indirectly support its attendant ill effects); do they 
challenge the institutions and ideas comprising our social structure, or are they somewhere in between the two poles? To put it in the vernacular, do they tend to be "part of the problem or part of the solution"?

The hypothesis at the outset of the study was that a range of views extending from one paradigm into the other would be discovered; that the social workers in the sample would tend to see poor clients' problems largely in practical terms; that they would have some awareness of the connections between social institutions and people's life problems, but that they would not show a clear or consistent ideological stand falling largely within either Paradigm I or Paradigm II. 


\section{CHAPTER II}

\section{REVIEW OF THE LITERATURE}

A search for relevant literature has yielded theoretical works about poverty and social work, a few studies similar in population and focus to the one presented here, studies of varying populations dealing with questions similar to those dealt with here, and studies of similar populations focusing on different but related issues.

James, in her recent book, Poverty, Politics, and Change, ${ }^{3}$ maintains that the profession of social work is dominated by "freudianism," which fits with the prevalent American value of individualism. This results in a heavy emphasis on interpersonal relations and individual growth and change, rather than focusing on social change. Everson's study of social workers' orientations further supports this thesis. ${ }^{4}$ He found a preference for philosophical positions emphasizing the self, the value of self-awareness and self-fulfillment, and a "rich inner life." One possible reason for this may be that the larger social problems are seen as too overwhelming to tackle, and the effort too ungratifying. Social workers feel relatively powerless to change social institutions. Everson implies that they therefore seek to work with clients in areas congruent with their own skills, such as

${ }^{3}$ James, pp. $72-103$.

${ }^{4}$ Bradford L. Everson, "Value Orientation in Relation to Emphasis in the Process of Diagnosing the Family in State of Crisis, "MSW the sis (PSU, 1969). 
interpersonal relationship problems. In so doing, perhaps they unintentionally negate important external forces. James also feels that the profession of social work has in recent times been more concerned with its own status and recognition than for social action to eradicate poverty.

Tussing ${ }^{5}$ differentiates two basic approaches to analyzing the causes of poverty--the "case approach," which focuses on the particular aspects of each individual's or family's situation; and "generic theories," which look for general, "economy-wide" causes. The case approach would implicitly tend to perpetuate what Ryan has called "blaming the victim, "6 by ignoring the impact of societal conditions on individuals and families. Tussing sees personal "inadequacies" such as poor physical or mental health and retardation as often being consequences, rather than causes, of poverty.

Schwartz ${ }^{7}$ comments on the "debate between causes and functions" (analogous to identifying and dealing with the root of the problem or treating its symptoms). He ventures that the ongoing debate may actually obscure the important links between "private troubles" and "public issues," implying that the connections must be understood in order to treat social problems such as poverty in an holistic way.

${ }^{5}$ A. Dale Tussing, Poverty in a Dual Economy (New York: St. Martin's Press, 1975). 1972).

${ }^{6}$ William Ryan, Blaming the Victim (New York: Vintage Books,

${ }^{7}$ William Schwartz, "Private Troubles and Public Issues: One Job or Two?" Lindeman Memorial Lecture, National Conference on Social Welfare (New York, May 28, 1969). 
Few studies have been done assessing the attitudes of social workers about the causes of and solutions to poverty. With the declaration of "war on poverty," the 1960s saw an upsurge in interest in doing empirical studies related to poverty, but most of these studied the poor themselves, rather than the social conditions or public attitudes that related to poverty. For example, in 1970 , one of the peak years of the "welfare boom," the Poverty and Human Resources Abstracts $^{8}$ volume lists 43 abstracts of articles under the heading "attitudes." Of these, all but about six have to do with attitudes of the poor, rather than attitudes toward the poor--studies probing poor people's motivation to work, the attitudes of blacks, lower and middle class value differences, attitudes toward employment, "who riots," self-concept, and attitudes of poor youth, attitudes about contraception, etc. Again, this seems indicative of a subtle (or not so subtle) attempt to find out "What is wrong with those people that makes them stay poor?"

Arangio 9 did one of the few studies that directly tackles the question of where social workers stand in their attitudes about poverty. He administered a questionnaire consisting of 45 items, using a Likert scale, to 2, 000 randomly sampled practicing social workers. The items had to do with "change targets, goals, and tactics," exemplifying either an "individual change" or a "social change" orientation. Of the

8"Poverty and Human Resources: Abstracts and Survey of Current Literature, " 5 (Institute of Labor and Industrial Relations: University of Michigan, Wayne State University, Ann Arbor, Michigan, 1970).

${ }^{9}$ Anthony Joseph Arangio, Ph. D. , "Individual Change or Institutional Change: Attitudes of Professional Social Workers Toward Change Targets, Goals, and Tactics" (Ph. D. dissertation at Tulane Univ., 1970). 
1,033 responses received, he found that most social workers were "strongly oriented toward individual change," and that most disagreed with tactics of a controversial nature on both the individual and institutional levels. This supports Epstein's 10 findings of a greater acceptance of "consensus strategies" than of "conflict strategies" among members of the New York City chapter of the National Association of Social Workers. On both the institutionalized and non-institutionalized levels, consensus strategies do not challenge or oppose peaceful negotiation through official channels, whereas conflict strategies do. Hence, there would seem to be inherent limitations to change efforts in using consensus strategies, yet Epstein found that the most approved strategies also tended to be seen as the most effective. He concluded that

the greater the institutional involvement of social workers in a problem area, the more conservative will be their perceptions of effective social action strategies for social workers as well as for other politically active groups. 11

Based on his data, Arangio developed profiles of social workers "most likely to support individual change" and those "most likely to support institutional change." The former were likely to be female social workers with over nine years of experience, working as direct service caseworkers or supervisors in county, state, or federal employment. The latter were likely to be unmarried male social workers with advanced degrees and less than nine years of experience,

${ }^{10}$ Irwin Epstein, MSW, "Social Workers and Social Action: Attitudes Toward Social Action Strategies, "Social Work, 13, No. 2 (Ann Arbor, Mich.: University of Michigan, April 1968)101-108.

${ }^{11}$ Epstein, pp. 106-107. 
working as community or group workers for a city, or as educators in a university setting. These data could have important implications when one looks at the composition, by sex, years of experience, and education, of workers in social service agencies.

A number of researchers have studied the attitudes of various American populations toward the poor. Though the studies cited are not about social workers per se, it may be inferred that the attitudes of social workers would not differ radically from those of the general public or those of members of other professions that deal with people. In any case; it is interesting to look at the results of studies similar to the ones previously mentioned.

In 1943, C. Wright Mills published a study he conducted on the ideology of sociology textbooks. ${ }^{12}$ He found that the authors of these textbooks, whom he refers to as "social pathologists," were a very homogeneous group from very similar backgrounds (usually of middle class, small town origins). He found that they also tended to share remarkably similar views on social problems, characterized by "a low level of abstraction" and a failure to consider how a broad perspective of the social structure relates to these problems. Their orientation seemed to lean toward practical issues of everyday life, and Mills commented that

A view of isolated and immediate problems as the "real" problems may well be characteristic of a society rapidly growing and expanding. . . the emphasis upon fragmentary, practical problems tends to atomize social objectives. The studies so informed are not integrated into designs

${ }^{12} \mathrm{C}$. Wright Mills, "The Professional Ideology of Social Pathologists, "American Journal of Sociology, 49, No. 2 (Sept. 1943), pp. $165-$ 180. 
comprehensive enough to serve collective action... 13

Lauer studied "how the middle class looks at poverty." 14 He administered an open-ended questionnaire to some 1,400 individuals of varying ages and occupations in the metropolitan St. Louis area, asking the question, "Why is there poverty in affluent America?" Operating under the premise that "The manner in which the nation approaches the problem of poverty will depend upon the way the nation sees its poor, "15 he found that the vast majority of his sample saw the poor as being "culpable rather than victimized." His respondents generally believed in individual initiative and responsibility and showed little or no concern or insight into the problems of poverty. They saw the principal causes as being laziness and lack of motivation; not wanting to work; lack of education, which they felt was available to anyone; and mismanagement of money on the part of the poor. Such attitudes, though commonplace, are clearly inconsistent with the facts-for example, that in 1967 less than 1 per cent of America's welfare recipients (numbering about 50,000 out of 7.3 million) were "potentially employable" males, ${ }^{16}$ not to mention that a good portion of the nation's families living under the poverty line are headed by fullyemployed males.

${ }^{13}$ Mills, pp. 168-169.

14 Robert H. Lauer, "The Middle Class Looks at Poverty," Urban and Social Change Review, 5, No. 1 (Fall 1971), 8-10.

16 James, p. 42 . 
Mc Donald ${ }^{17}$ studied a three-generational group of citizens to find out who they thought deserved help in terms of financial and social services. He found that those who were poor due to personal misfortunes, ill health, accident, or old age were considered to be "deserving poor." Widows and divorced women with preschool children were found to be slightly "less deserving" of help. Unmarried teenage mothers were considered to be even less deserving, while people who were poor due to class, race, lack of opportunity and mainly economic reasons, such as blacks and Mexican Americans, were considered to be least deserving of help.

A cross-class and -race study of attitudes (of the general public) done by Rytina, Forum, and Pease ${ }^{18}$ found class-related differences in attitudes about the causes of poverty. The sample of heads of households (from Muskegon, Illinois) was divided into five groups: "rich whites" (with annual incomes over \$25,000), "middle whites" and "middle blacks," and "low whites" and "low blacks" (with annual incomes under $\$ 3,500$ for a family of four). They found that the rich were more convinced than the poor that wealth is a result of favorable personal attributes (72 per cent of the rich, compared to 17 per cent

17 Archie Donald McDonald, DSW, "Attitudes Toward the Legitimacy of Public Intervention on Behalf of Poor Persons: Correlates and Consequences of Three Generations, "DSW dissertation (University of Southern California, 1971).

18 Joan Huber Rytina, William H. Forum, and John Pease, "Income and Stratification Ideology Beliefs About the American Opportunity Structure," American Journal of Sociology, 75, No. 4, Part 2 (Jan. 1970), 703-7 16 . 
of poor blacks). ${ }^{19}$ They also found that 80 per cent of the rich and 60 per cent of middle class whites thought that relief status within the last six years was the result of personal characteristics, while less than 50 per cent of the remaining groups thought so.

Livingston did an interesting study of the attitudes of male high school seniors using a simulation game called "Ghetto. "20 The boys played the game, which had them take on the roles of ghetto residents, for four class sessions. He found that their attitudes toward the poor were significantly more favorable after this experience, but he also found a significant decline in interest in the game. He speculated that this may have been partly due to the frustrations of dealing with problems of poverty.

Vail $^{21}$ did a study of social and cultural factors in casework diagnosis, using a random sample of practitioners who were alumni of the Smith College School of Social Work, as well as the school's entire 1969 student population. She found that workers' assessments of a client's treatment plans and expectations in the treatment situation were affected by the client's socioeconomic class, though not by the client's race or the worker's level of experience. With poor clients, the respondents felt it would be important to discourage self-pity,

${ }^{19}$ Rytina, pp. $713-714$.

${ }^{20}$ Samuel A. Livingston, "Simulation Games and Attitude Change: Attitudes Toward the Poor, "Johns Hopkins University, Center for the Study of Social Organization of Schools (Baltimore, Md., April 1970), ] 4 pp.

${ }^{21}$ Susan Vail, "The Effects of Socioeconomic Class, Race, and Level of Experience on Social Virorkers' Judgments of Clients, "Smith College Studies in Social Work, 40, No. 3 (June, 1970). 236-246. 
whereas discouragement of intellectualization was considered important in working with middle class clients. This seems to point to a difference in treatment orientations, depending on the client's class.

Vail quotes Meier:

... although the caseworker is highly skilled in knowing how to assess those personal determinants that are located in life experiences specific to the individual, he has not yet developed comparable skill in recognizing stresses and pressures which arise from the social structure and the culture. 22

The aforementioned studies, although not all directly related to social work, seem to fit together like pieces of a puzzle to form a picture of how America sees its poor. The data show that social workers tend to focus on individual change, and that when they get involved with broader issues, they disapprove of conflict strategies which are disruptive or unconventional. In working with individual clients, their diagnoses, treatment plans, and expectations of success vary according to the socioeconomic class of the client.

Even the authors of sociology textbooks seem to share with the general public a narrow view of social conditions related to poverty, often implicitly blaming the poor themselves for their unfortunate situation, attributing the major cause to their own "inadequacy" or lack of initiative.

Perhaps the most provocative study is Livingston's, which hịts that the problems of poverty are very frustrating for whomever attempts to grapple with them; hence, they tend to be avoided by those who can afford to avoid them. Only the poor cannot.

$$
{ }^{22} \text { Vail, p. } 15
$$


An examination of the data from this study will attempt to look at whether the sample's attitudes fit into and support the foregoing description. 


\section{CHAPTER III}

\section{RESEARCH DESIGN AND METHODOLOGY}

\section{The Instrument}

Data for the study was collected by means of a questionnaire. The questionnaire attempted to assess the sample of local social workers' attitudes about poverty. The purpose was to assess their attitudes in relation to Warren's Paradigms I and II, as described in Chapter II.

A questionnaire consisting of two parts was developed. ${ }^{2} 3$ Part I was designed to measure the respondent's beliefs about the causes of and solutions to poverty on a general level. This was operationalized by asking the respondent, a social worker, to imagine being in the following hypothetical situation: you are asked to give a speech on the topic "Poverty in America: Its Causes and Cures" to a college class in social welfare. After being presented with this situation, the respondents were given a series of 16 statements, each reflecting a particular stance about the causes and cures of poverty. The respondents were asked to read each statement and decide whether he/she agreed with it or disagreed with it, and whether they would include it in their talk. An example of such a statement is:

A crucial reason this country hasn't been able to solve poverty is because the government's first allegiance is to large corporations who put profits before people.

\section{${ }^{23}$ See Appendix A.}


There were four possible responses to each statement. ${ }^{24}$ These were as follows: agree and would include in the talk; agree but wouldn't include; disagree and would include to refute; disagree and wouldn't include. In analyzing the data, the first two were counted as "agree" responses and the last two as "disagree" responses. (For the purposes of this study, the important distinction was between agreement and disagreement.)

Part II of the questionnaire was constructed with the same format as Part I. Again, the respondent is asked to put himself/herself in a situation and respond to statements pertaining to it. The purpose of Part II is to assess the respondents' attitudes about actions they would take in dealing with poverty, on either the direct service or the planning level. One version of Part II, dealing with a casework situation involving a young black welfare mother, was developed for direct-service field instructors. Another version, dealing with the task of developing programs to aid welfare families, was devised for planning field instructors.

Again, the respondents are asked to read the statements following the situation description and decide whether they find them highly relevant actions they would be sure to pursue or support; somewhat relevant and would probably pursue or support; somewhat irrelevant and probably wouldn't pursue or support; or highly irrelevant and certainly wouldn't pursue or support. As in Part I, the critical distinction for the purposes of this study is between a basically positive or

\section{${ }^{24}$ See Appendix A.}


negative response.

As developed, each of the statements throughout the questionnaire fits into either Paradigm I or Paradigm II. The paradigms refer to specific contexts in which to understand and deal with social problems. As described in Chapter I, the Paradigm I perspective holds that poverty has its roots in the deficiencies of individuals, while Paradigm II maintains that the causes of poverty lie in structural inequities within our social institutions.

For the purposes of this study, each paradigm was broken down into two sub-categories of attitudes. It was hypothesized that the attitudes of the social workers being studied would not fit neatly into one or the other paradigm. It was also felt that each paradigm in itself covered a broad range of views, from conservative to radical, and that it would be valuable to assess exactly where the attitudes under study fit along this ideological continuum. It was hypothesized that, in reality, measuring attitudes is not a "black and white" process, as Warren's sharp distinction between Paradigms I and II might indicate. Therefore, it would be important to develop an instrument that could, to some extent, measure "shades of grey," or the middle ground into which many attitudes might fall.

Hence, Paradigm I was broken down into the sub-categories "conservative" and "liberal." The conservative position is defined as one which sees the causes of poverty lying largely in inadequacies, deficiencies, or maladaptations of individuals or groups of poor people (such as ethnic minorities). From this perspective, the poor are seen as basically inferior beings. Theories of genetic inferiority fall into 
this category. Also included are theories of psychological maladjustment, theories about the "culture of poverty" as being dysfunctional, and theories of lack of motivation for acquiring education and employable skills.

Dealing with poverty from this point of view, change efforts are focused on therapy or casework for individuals or groups. The goals are to correct psychological maladjustment and change defective values; to help the poor better adapt to society and function in accordance with social norms. Change efforts are also directed at helping them to improve their ability to cope with social stress and to take advantage of available opportunities for self-betterment. Within this category, there is often a punitive approach to dealing with those who "fail" to adjust and succeed in spite of help. The following is an example of a statement from this category:

If there were enough mental health and rehabilitation centers to reach all poor and disadvantaged people, our society could deal effectively with the problem of poverty. (Part I.)

The liberal Paradigm I position also sees the causes of poverty as lying in the inadequacies of individuals or groups, but this position is less directly "blaming." It sees the deficiencies of the poor as resulting from lack of opportunity for adequate education and training, and discrimination based on race or ethnic origin. The poor are not seen as being inherently inferior, but "inferior" due to circumstances. However, they still must shoulder the burden of change. From this perspective, opportunities will be provided for the poor and disadvantaged to get the education and skills they need. It is up to them to take advantage of these opportunities and, beyond that, to try to "make it" 
within the accepted social system. Within this category there is an emphasis on self-fulfillment and self-actualization through rehabilitative efforts. The following is an example of a liberal Paradigm I statement:

I would suggest to Melba that perhaps enrolling in some courses at the local community college (for which a high school diploma is not required) would give her a chance to learn and do something interesting. (Part II.)

Paradigm II was broken down into the sub-categories "liberal" and "radical." The focus of the liberal Paradigm II position shifts from the poor themselves to the organizations and institutions the poor must deal with. This is a structural view, but it falls short of looking at society in its totality. It does not examine how the various institutions interact and affect the quality of life in general. Instead, it singles out specific organizations, such as public welfare, that directly affect the lives of the poor. Flaws and weaknesses of organizations are identified, and change efforts are directed at organizational reform. This might include modifying and improving the functioning of the welfare system and humanizing the delivery of social services. However, the assumption of the basic soundness of the social order is never actively challenged.

Social action or legislation with the goal of specific organizational reform falls into this category, as do individual and interest group advocacy. The change target remains the organization, not the poor, who are seen as victims of inadequate or dehumanizing systems. There is also an emphasis on helping poor people to obtain their full legal rights under existing laws. An example of a liberal Paradigm II item is as follows: 
I would propose the development of an inter-agency coordinating council, so that the various community agencies providing social services to families could coordinate and balance each other's efforts. (Part II.)

The radical Paradigm II position looks at society as a whole. It sees the causes of poverty lying in inequities within its basic structure and institutions, including organizations and underlying values and ideologies. This perspective encompasses a critique of the inequality of existing social relations in terms of the distribution of money and power. It challenges our capitalist economic system and sees the only real solution to poverty as lying in the radical transformation of this system into a socialistic one. Again, poverty is seen as a symptom of a social system with built-in inequities, and the poor are seen as its inevitable victims.

Any social action or legislation leading to change in the direction of redistribution of income or power within society falls into the radical category. Also included are efforts at consciousness-raising among the poor to develop in them this awareness of the causes of poverty. An example of a radical Paradigm II statement is as follows:

Poverty and unemployment will not be eradicated as long as we have a free enterprise economy, for they are necessary for its functioning (by keeping wages down and providing cheap labor). (Part I.)

An equal number of items was developed for each of these four categories. The items were randomly distributed within each section of the questionnaire.

The reader may wonder why a complete set of sub-categories (conservative, liberal, and radical) was not developed for each of the two paradigms. It is believed that attitudes fitting categories which could be labeled "radical Paradigm I" and "conservative Paradigm II" 
do exist. However, it was felt that beliefs or actions exemplifying these attitudes were relatively uncommon. Hence, they were omitted in the development of the questionnaire.

It is further assumed that respondents who would agree with, for example, a radical Paradigm I statement, would also tend to agree with a radical Paradigm II statement. The as sumption was made that including a full range of categories in each paradigm would not have altered the results of the study significantly.

The intention of assessing the respondents' attitudes in terms of the categories described above is not to imply that any one perspective is "the right one, "or that some are "right" and others are "wrong." Rather, the premise is that there is some validity in each one, and that all of them may be important. The study is an attempt to describe where the respondents' attitudes lie within this range; whether they tend to cluster in particular categories; whether they de-emphasize or exclude others; or whether there is an even spread.

This is not to say that value judgments about the different perspectives are inappropriate. However, in making such judgments one must avoid being simplistic and evaluating them by "all or nothing" criteria. This study does not attempt to deal with the more complex questions of which manifestations of a particular attitudinal category are beneficial to poor people and which are harmful. It is simply a descriptive study attempting to as sess what the sample's attitudes are in relation to these categories.

The Sample

The study sample consists of 94 of the 98 field instructors for the 
Portland State University School of Social Work for the academic year 1975-1976. These instructors work in a variety of social service agencies and positions in and around the Portland metropolitan area. They supervise social work students doing direct service casework and planning or administration on a part-time basis.

The sample includes 79 (84 per cent) field instructors for students in the direct service tract and 15 (16 per cent) field instructors for students in the planning tract. It consists of 52 (55 per cent) men and 42 (45 per cent) women.

Out of 94 questionnaires sent out, a total of 64 responses $(68$ per cent) was received. Of these, 55 (86 per cent) were from direct service instructors and 9 (14 per cent) from planning instructors. The relatively low return rate is due in part to a coding error which made it impossible to tell in many cases whose responses had been received and whose hadn't. Although this had no effect on analysis of the data received, it made impossible an efficient and strategic use of follow-up phone calls in order to bolster the return rate. The return rate for each of the two groups was in close proportion to their representation in the total sample.

Among the respondents, 37 (58 per cent) were men and 27 (42 per cent) women. Thirty-three (52 per cent) of the respondents had over nine years of experience in the field, and 31 (48 per cent) had less than nine years of experience. ${ }^{25}$ The direct service respondents include supervisors, program directors, and administrators working in direct

25 A criterion found in Arangio's profiles of social workers, described in Chapter II. 
service agencies.

Since this is a non-probability sample, the results of the study are simply descriptive and cannot be generalized. However, they may suggest hypotheses to be tested through further study.

\section{Collection of Data}

A pretest of the questionnaire was done with a small group of graduate students. Minor modifications were made based on feedback from the pretest respondents, but the instrument was found to be basically sound.

Following the pretest and refinements, the questionnaire was mailed with a cover letter ${ }^{26}$ and self-addressed, stamped return envelope to the sample. The respondents were given a two-week deadline by which to complete and return the questionnaire. At the end of this period, one round of follow-up phone calls was made.

There were no serious data collection problems, as the spontaneous responses, coupled with follow-up phone calls, yielded an adequate though not remarkable return rate (68 per cent). However, due to a coding oversight, it was not possible to determine by name which members of the sample had and had not returned the questionnaire. Although this posed no problem in analyzing data from the responses, it made it impossible to determine whether the group who did not respond were distinguished in any way from the group who did.

\footnotetext{
${ }^{26}$ See Appendix A.
} 


\section{CHAPTER IV}

\section{RESULTS, CONCLUSIONS, AND LIMITATIONS}

\section{Factor Analysis--Introduction}

A factor analysis of the questionnaire was done in crder to assess whether the questionnaire actually measured the attitudes it was designed to measure. In developing the questionnaire, four distinct attitudinal categories were defined, as described in Chapter III. These categories were based on Warren's Paradigms I and II--theoretical frameworks in which to understand the causes of and solutions to poverty.

A Paradigm I perspective implies that individuals or groups of poor people are held primarily responsible for their poverty and for using their own initiative to rise out of it. A Paradigm II perspective maintains that the causes of poverty lie within structural (or "built-in") inequalities within our social institutions, such as the economic system. It holds that the only way to eliminate poverty on a mass scale would be to make necessary changes in these systems.

In developing the questionnaire, each of these broad categories was broken down into two sub-categories of attitudes in order to make finer discriminations. Paradigm I was broken into a "conservative" and a "liberal" category. Paradigm II was broken into a "liberal" and a "radical" category. An equal number of items was developed for each of these categories, and they were randomly distributed throughout the questionnaire. The assumption was made that items within the same 
category had a factor or factors in common. Therefore, it was hypothesized that respondents would tend to agree with all items within the same category, depending on which fit their attitudinal biases. The factor analysis was done in an attempt to see whether this assumption was valid--whether the respondents indeed perceived common factors among the items in each specific category. This could be discerned by analysis of their patterns of agreement and disagreement.

Factor Analysis of Part I

A factor analysis of Part I of the questionnaire did not tend to support the aforementioned assumption. The analysis uncovered a total of six factors. This finding indicates that the respondents perceived some differences between items beyond those that were intended on the basis of the four categories alone.

In examining the items with factor loadings over. 5 , it was found that they did not tend to group into the categories they were developed for. 27 For three out of six factors, all the items with either positive

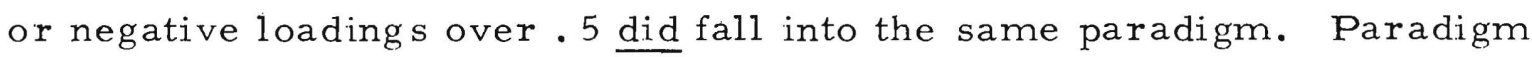
I items tended to group together and Paradigm II items tended to group together. Hence, it can be ventured that the respondents were able to perceive some distinction between the paradigms. However, they apparently did not clearly perceive the intended distinctions between the sub-categories within each paradigm, or the items didn't quite measure what they were intended to.

${ }^{27}$ See Table I, p. 28. 
TABLE I

FACTOR ANALYSIS--PART I

\begin{tabular}{|c|c|c|c|c|}
\hline Factor & $\underset{\#}{\text { Item }}$ & Description & Category & $\begin{array}{l}\text { Factor } \\
\text { Loadings }\end{array}$ \\
\hline 1 & $\begin{array}{l}10 \\
16\end{array}$ & $\begin{array}{l}\text { education and vocational } \\
\text { training } \\
\text { stigma and dehumanization } \\
\text { of welfare }\end{array}$ & $\begin{array}{l}\text { PI-L } \\
\text { PII-L }\end{array}$ & $\begin{array}{l}0.7337 \\
0.7707\end{array}$ \\
\hline 2 & $\begin{array}{r}3 \\
12\end{array}$ & $\begin{array}{l}\text { attitudes of the poor } \\
\text { "poverty pockets" }\end{array}$ & $\begin{array}{l}\text { PI-C } \\
\text { PI-L }\end{array}$ & $\begin{array}{l}0.7136 \\
0.7185\end{array}$ \\
\hline 3 & $\begin{array}{l}13 \\
15\end{array}$ & $\begin{array}{l}\text { non-acceptance of birth } \\
\text { control } \\
\text { manpower programs }\end{array}$ & $\begin{array}{l}\text { PI-C } \\
\text { PI-L }\end{array}$ & $\begin{array}{l}0.7911 \\
0.7401\end{array}$ \\
\hline 4 & $\begin{array}{l}1 \\
2 \\
7\end{array}$ & $\begin{array}{l}\text { deferring need gratification } \\
\text { government-planned } \\
\text { economy } \\
\text { poverty due to racial } \\
\text { prejudice }\end{array}$ & $\begin{array}{l}\text { PI-C } \\
\text { PII-R } \\
\text { PII-L }\end{array}$ & $\begin{array}{r}-0.7454 \\
0.5728 \\
0.6294\end{array}$ \\
\hline 5 & $\begin{array}{r}7 \\
9 \\
14\end{array}$ & $\begin{array}{l}\text { poverty due to racial } \\
\text { prejudice } \\
\text { poor people's labor } \\
\text { movement } \\
\text { awareness of legal rights }\end{array}$ & $\begin{array}{l}\text { PII-L } \\
\text { PII-R } \\
\text { PII-L }\end{array}$ & $\begin{array}{r}0.6294 \\
-0.7917 \\
-0.6047\end{array}$ \\
\hline 6 & $\begin{array}{l}4 \\
8\end{array}$ & $\begin{array}{l}\text { developing job opportunities } \\
\text { mental health and } \\
\text { rehabilitation centers }\end{array}$ & $\begin{array}{l}\text { PII- L } \\
\text { PI-C }\end{array}$ & $\begin{array}{l}-0.5678 \\
-0.8056\end{array}$ \\
\hline
\end{tabular}


Factor Analysis of Part II

The factor analysis of Part II (Direct Service version) of the questionnaire tended to support the assumption that the items within each category had factors in common. A total of five factors was uncovered; within Paradigm I, the grouping of items by factor loadings

over. 5 coincided closely with the categories developed. ${ }^{28}$ This indicates that the respondents perceived these items as having factors in common, as intended. The only exception was item No. 16, which had to do with taking courses at a community college and did not load significantly on any factor.

The analysis revealed a complete separation, by factors, between Paradigm I and Paradigm II items. However, within Paradigm II, there was no clear separation between liberal and radical items. All the radical items loaded on the same factor along with two liberal items. $^{29}$ One radical item loaded on another factor together with a liberal item; and one liberal item, having to do with low-cost housing, stood by itself with a separate factor. This indicates that the respondents did not clearly perceive the intended distinctions between the liberal and radical Paradigm II items, although they did perceive a clear distinction between Paradigms I and II.

\section{Conclusions}

The results of the factor analysis indicate that the respondents generally perceived distinctions between the paradigms as intended,

\footnotetext{
${ }^{28}$ See Table II, p. 30.

${ }^{29}$ See Table II, p. 30.
} 
TABLE II

FACTOR ANAL YSIS--PART II (DIRECT SER VICE)

\begin{tabular}{|c|c|c|c|c|}
\hline $\begin{array}{c}\text { Factor } \\
\#\end{array}$ & $\begin{array}{c}\text { Item } \\
\#\end{array}$ & Description & Category & $\begin{array}{l}\text { Factor } \\
\text { Loadings }\end{array}$ \\
\hline 1 & $\begin{array}{r}1 \\
3 \\
5 \\
8 \\
11 \\
15\end{array}$ & $\begin{array}{l}\text { Welfare Rights organization } \\
\text { referral } \\
\text { demonstration protesting } \\
\text { welfare payments } \\
\text { channel depression into } \\
\text { anger } \\
\text { advocate for clients } \\
\text { financial problems } \\
\text { organizing workers } \\
\text { and clients } \\
\text { critical books on } \\
\text { American society }\end{array}$ & $\begin{array}{l}\text { PII-L } \\
\text { PII-R } \\
\text { PII-R } \\
\text { PII-L } \\
\text { PII-R } \\
\text { PII-R }\end{array}$ & $\begin{array}{l}0.5875 \\
0.8651 \\
0.8818 \\
0.6617 \\
0.5777 \\
0.7547\end{array}$ \\
\hline 2 & $\begin{array}{r}4 \\
7 \\
13\end{array}$ & $\begin{array}{l}\text { vocational training or GED } \\
\text { WIN program } \\
\text { single mothers' support } \\
\text { group }\end{array}$ & $\begin{array}{l}P I-L \\
P I-L \\
P I-L\end{array}$ & $\begin{array}{l}0.7035 \\
0.8901 \\
0.7609\end{array}$ \\
\hline 3 & $\begin{array}{r}2 \\
6 \\
9 \\
9 \\
12\end{array}$ & $\begin{array}{l}\text { feelings about herself } \\
\text { money management } \\
\text { counseling } \\
\text { examining "lifescript" } \\
\text { long-term counseling }\end{array}$ & $\begin{array}{l}\mathrm{PI}-\mathrm{C} \\
\mathrm{PI}-\mathrm{C} \\
\mathrm{PI}-\mathrm{C} \\
\mathrm{PI}-\mathrm{C}\end{array}$ & $\begin{array}{l}-0.7225 \\
-0.5655 \\
-0.6848 \\
-0.6525\end{array}$ \\
\hline 4 & 10 & low-cost housing & PII-L & -0.9659 \\
\hline 5 & 11 & $\begin{array}{l}\text { organizing workers } \\
\text { and clients } \\
\text { advocate with landlord } \\
\text { and welfare department }\end{array}$ & $\begin{array}{l}\text { PII-R } \\
\text { PII-L }\end{array}$ & $\begin{array}{l}0.5152 \\
0.7315\end{array}$ \\
\hline
\end{tabular}


but that they did not clearly perceive the intended political philosophy distinctions between the sub-categories within each paradigm. The exception to this was in Part II of the questionnaire, for Paradigm I items. These items were perceived to have factors in common almost exactly as intended.

In general, the results of the factor analysis do not support the hypothesis that respondents would tend to agree with all items within the same category. Therefore, it cannot be assumed or verified that the instrument measured the attitudes it was designed to measure.

No attempt was made to describe the factors that were uncovered by the analysis, according to the content of the items that grouped together.

\section{DATA ANALYSIS: PART I}

The hypothetical situation presented in Part I of the questionnaire was as follows:

You are asked to give a guest lecture for a college course entitled "Introduction to Social Work" on the subject "Poverty in America: Its Causes and Cures."

This situation was followed by a list of 16 statements having to do with the causes and cures of poverty. ${ }^{30}$ The responses to the situation were analyzed in terms of which statements were agreed with. "Agree" responses include "Agree and would include in my speech," as well as "Agree but would not include in my speech." The important distinction for the purposes of this study was which items the

${ }^{30}$ See Appendix A. 
respondents tended to agree with, whether this agreement was certain or tentative. The object was to assess how many "agree" responses there were, on the average, within each attitudinal category. This would indicate which category or categories the attitudes of the sample would tend to fit into.

\section{Hypotheses}

The hypotheses made about the responses to Part I of the questionnaire, dealing with beliefs about poverty's causes and solutions, were as follows:

1. The respondents will be more likely to agree with Paradigm II (institutional responsibility) statements than Paradigm I (individual responsibility) statements.

2. The majority of respondents will agree with more liberal statements (in either Paradigm I or Paradigm II) than conservative or radical statements combined.

3. The majority of individual items with high agreement rates (operationally defined as 75 per cent) will fall into the two "liberal" categories.

$\underline{\text { Results }}$

It was found that, overall, there were more "agree" responses (58 per cent) than "disagree" or non-responses. 31 The data show that the respondents as a group were able to respond to the items with either agreement or disagreement at least 95 per cent of the time. An analysis of the "agree" responses indicates that the respondents were somewhat more likely to agree with Paradigm II than Paradigm I statements.

${ }^{31}$ See Table III, p. 33. 
TABLE III

PERCENTAGE OF AGREES, DISAGREES

AND NON-RESPONSES*

\begin{tabular}{|l|c|c|c|}
\hline \multicolumn{1}{|c|}{ Part } & Agrees & Disagrees & Non-responses \\
\hline \begin{tabular}{l} 
I $(\mathrm{n}=64 ;$ total responses=1024) \\
\hline $\begin{array}{l}\text { II (Direct Service-- } \\
\mathrm{n}=55 ; \text { total responses=880) }\end{array}$
\end{tabular} & $58 \%$ & $40 \%$ & $2 \%$ \\
\hline $\begin{array}{l}\text { II (Planning-- } \\
\mathrm{n}=9 ; \text { total responses=144) }\end{array}$ & $65 \%$ & $35 \%$ & $5 \%$ \\
\hline
\end{tabular}

*For Part I, "Agrees" include "agree and would include in my talk" and "agree but would not include in my talk." "Disagrees" include "disagree but would include in my talk to refute" and "disagree and would not include in my talk.

For Part II, "Agrees" include "highly relevant" and "somewhat relevant." "Disagrees" include "somewhat irrelevant" and "highly irrelevant." 
As described in Chapter III, the 16 statements listed after the hypothetical situation are evenly divided between the two paradigms and the four sub-categories (two within each paradigm). Therefore, the number of possible "agree" responses in each of these categories ranges from 0 to 4 . The data were analyzed in terms of the mean number of "agree" responses per category. It was found that the highest mean number of "agree" responses occurred in the liberal Paradigm II category (3.47 out of a possible 4). The lowest mean number of "agree" responses occurred in the conservative Paradigm I category ( 1.97 out of a possible 4$).^{32}$ These data indicate that the respondents were more likely to conceptualize poverty as being a result of inequalities within the structure of society than to as sign major responsibility to the poor themselves.

These data were also analyzed in terms of the percentage of respondents agreeing with more Paradigm I than Paradigm II statements, the percentage agreeing with more Paradigm II than Paradigm I statements, and the percentage agreeing with an even number of each. The object here was to get an overall picture of which paradigm the respondents' attitudes tended to fit into, without breaking down into the sub-categories. The results of this analysis were consistent with the results of the one previously discussed. It was found that a majority of respondents agreed with more Paradigm II than Paradigm I statements (78 per cent as compared to 14 per cent). ${ }^{33}$ This finding further

$$
\begin{aligned}
& 32 \text { See Table IV, p. } 35 . \\
& { }^{33} \text { See Table V, p. } 36 .
\end{aligned}
$$


TABLE IV

MEAN NO. OF "AGREES" PER CATEGORY

(FROM 0-4)

\begin{tabular}{|l|c|c|c|c|}
\hline \multirow{2}{*}{ Sample Group } & \multicolumn{2}{|c|}{ Paradigm I } & \multicolumn{2}{c|}{ Paradigm II } \\
\hline $\begin{array}{l}\text { Part I } \\
\text { (Total Group) } \\
\text { n=64 }\end{array}$ & Conservative & Liberal & Liberal & Radical \\
\cline { 2 - 5 } & 1.97 & 2.02 & 3.47 & 2.19 \\
\hline $\begin{array}{l}\text { Part II } \\
\text { (Direct Service) } \\
\text { n=55 }\end{array}$ & 2.42 & 3.13 & 2.82 & 1.24 \\
\hline $\begin{array}{l}\text { Part II } \\
\text { (Direct Service-- } \\
\text { Less than 9 years } \\
\text { experience) } \\
\text { n=26 }\end{array}$ & 2.27 & 3.08 & 2.85 & 1.50 \\
\hline $\begin{array}{l}\text { Part II } \\
\text { (Direct Service-- } \\
\begin{array}{l}\text { More than9 years } \\
\text { experience) } \\
\text { n=29 }\end{array}\end{array}$ & 2.55 & 3.17 & 2.79 & 1.00 \\
\hline
\end{tabular}


TABLE V

COMPARISON OF AGREEMENTS WITH

PAR ADIGM I AND PARADIGM II

STATEMENTS

\begin{tabular}{|l|c|c|c|}
\hline \multicolumn{1}{|c|}{ Sample Group } & $\begin{array}{l}\text { \% Agreeing With } \\
\text { More Paradigm I } \\
\text { Statements }\end{array}$ & $\begin{array}{l}\text { More Pgreeing With } \\
\text { Statements }\end{array}$ & $\begin{array}{c}\% \text { Evenly } \\
\text { Divided } \\
\text { Between } \\
\text { Paradigms }\end{array}$ \\
\hline $\begin{array}{l}\text { Part I } \\
\text { (Total Group) } \\
\text { n=64 }\end{array}$ & $14 \%$ & $78 \%$ & $8 \%$ \\
\hline $\begin{array}{l}\text { Part II } \\
\text { (Direct Service) } \\
\text { n=55 }\end{array}$ & $58 \%$ & $20 \%$ & $22 \%$ \\
\hline $\begin{array}{l}\text { Part II } \\
\text { (Direct Service-- } \\
\text { Less than9 years } \\
\text { experience) } \\
n=26\end{array}$ & $42 \%$ & $23 \%$ & $35 \%$ \\
\hline $\begin{array}{l}\text { Part II } \\
\text { (Direct Service-- } \\
\text { More than 9 years } \\
\text { experience) } \\
n=29\end{array}$ & $72 \%$ & $17 \%$ & $10 \%$ \\
\hline
\end{tabular}


supports the hypothesis that the sample was more likely to conceptualize poverty as being the result of social conditions and structural inequalities than of individual defects.

The data were analyzed to see whether the majority of respondents agreed with more liberal statements (in either paradigm) than conservative and radical statements combined. The liberal categories represent the moderate component of each paradigm. As described in Chapter III, the Paradigm I liberal category represents an attitude placing ultimate responsibility for solving poverty on the poor themselves. The problem is seen in terms of lack of opportunity for adequate education and training, rather than in terms of inherent deficiencies of the poor. Within this framework, solutions are seen in providing more opportunities, but the poor must use their own initiative to take advantage of them. Inadequacies and inequities of social institutions themselves are not dealt with.

The conservative Paradigm I perspective maintains that poor people are directly "to blame" for their situation because of their failure or refusal to incorporate dominant social values. It was hypothesized that the respondents would not tend to agree with this more extreme position; rather that they would tend to agree with the liberal one:

The liberal Paradigm II category encompasses the belief that poverty is largely a result of inadequate, ineffective, or dehumanizing organizations such as the welfare system. This perspective assumes that if these organizations were reformed and could meet the needs of the poor adequately, that over time the poor would be helped to rise 
out of poverty. The radical Paradigm II position maintains that not only must organizations be reformed to deal with poverty, but the basic institutions and values of our society must be restructured to eliminate imbalances of power and income distribution. Again, it was hypothesized that the respondents would tend to agree with the liberal rather than the radical Paradigm II position.

The findings show that a solid majority ( 81 per cent) of the respondents agreed with more liberal than either conservative or radical statements in Part I of the questionnaire, ${ }^{34}$ thereby supporting the hypothesis.

An analysis was done of the "agree" response rates of individual items. The data were examined to see which items had a high "agree" response rate (over 75 per cent of respondents agreeing), and which attitudinal categories these items represented. The hypothesis was that the highest consensus of agreement among the respondents would be on items in the liberal categories. This hypothesis was supported by the data. Six out of the seven items with high "agree" rates were found to belong in the liberal categories. ${ }^{35}$ Four of these were in Paradigm II and three in Paradigm I.

There were only two items in Part I of the questionnaire that showred a high rate of disagreement lover 75 per cent of the respondents disagreeing). ${ }^{36}$ These items had to do with public assistance destroying

\footnotetext{
${ }^{34}$ See Table VI, p. 39.

${ }^{35}$ See Table VII, p. 40.

${ }^{36}$ See Appendix A.
} 
TABLE VI

COMPARISON OF AGREEMENTS WITH

LIBERAL AND CONSERVATIVE AND

RADICAL STATEMENTS

\begin{tabular}{|l|c|c|c|}
\hline \multicolumn{1}{|c|}{ Sample Group } & $\begin{array}{c}\text { \% Agreeing With } \\
\text { More Liberal } \\
\text { Statements }\end{array}$ & $\begin{array}{c}\% \text { Agreeing With } \\
\text { More Radical } \\
\text { and Conservative } \\
\text { Statements }\end{array}$ & $\begin{array}{c}\% \text { Evenly } \\
\text { Divided } \\
\text { Between } \\
\text { Groups }\end{array}$ \\
\hline $\begin{array}{l}\text { Part I } \\
\text { Total Group) } \\
\text { n=64 }\end{array}$ & $81 \%$ & $6 \%$ & $13 \%$ \\
\hline $\begin{array}{l}\text { Part II } \\
\text { (Direct Service) } \\
\text { n=55 }\end{array}$ & $80 \%$ & $9 \%$ & $11 \%$ \\
\hline $\begin{array}{l}\text { Part II } \\
\text { (Direct Service-- } \\
\text { Less than 9 years } \\
\text { experience) } \\
n=26\end{array}$ & $73 \%$ & $8 \%$ & $19 \%$ \\
\hline $\begin{array}{l}\text { Part II } \\
\text { (Direct Service-- } \\
\begin{array}{l}\text { More than 9 years } \\
\text { experience) } \\
\text { n=29 }\end{array}\end{array}$ & $86 \%$ & $10 \%$ & $3 \%$ \\
\hline
\end{tabular}


TABLE VII

ITEMS WITH HIGH AGREEMENT RATE

\begin{tabular}{|c|c|c|c|}
\hline Part & $\begin{array}{l}\text { Item \# \& } \\
\text { Category }\end{array}$ & Description & $\begin{array}{l}\% \text { of } \\
\text { Re spondents } \\
\text { Agreeing }\end{array}$ \\
\hline I & $\begin{aligned} 4 & (\mathrm{PII}-\mathrm{L}) \\
7 & (\mathrm{PII}-\mathrm{L}) \\
10 & (\mathrm{PI}-\mathrm{L}) \\
11 & (\mathrm{PI}-\mathrm{L}) \\
14 & (\mathrm{PII}-\mathrm{L}) \\
15 & (\mathrm{PI}-\mathrm{L}) \\
16 & \text { (PII-L) }\end{aligned}$ & $\begin{array}{l}\text { developing job opportunities } \\
\text { poverty due to racial prejudice } \\
\text { education \& vocational training } \\
\text { government's allegiance } \\
\text { to corporations } \\
\text { awareness of legal rights } \\
\text { manpower programs } \\
\text { stigma \& dehumanization } \\
\text { of welfare }\end{array}$ & $\begin{array}{l}86 \% \\
95 \% \\
78 \% \\
77 \% \\
91 \% \\
81 \% \\
78 \%\end{array}$ \\
\hline $\begin{array}{l}\text { II } \\
\text { (Direct } \\
\text { Service-- } \\
\text { Total } \\
\text { group) }\end{array}$ & $\begin{aligned} 4 & (\mathrm{PI}-\mathrm{L}) \\
7 & (\mathrm{PI}-\mathrm{L}) \\
10 & (\mathrm{PII}-\mathrm{L}) \\
13 & (\mathrm{PI}-\mathrm{L}) \\
14 & (\mathrm{PII}-\mathrm{L})\end{aligned}$ & $\begin{array}{l}\text { vocational training or GED } \\
\text { WIN program } \\
\text { low-cost housing } \\
\text { single mothers' support group } \\
\text { advocate with landlord and } \\
\text { welfare department }\end{array}$ & $\begin{array}{l}84 \% \\
84 \% \\
96 \% \\
85 \% \\
76 \%\end{array}$ \\
\hline $\begin{array}{l}\text { II } \\
\text { (Direct } \\
\text { Service-- } \\
\text { Less than } \\
9 \text { years } \\
\text { experience) }\end{array}$ & $\begin{aligned} 4 & (\mathrm{PI}-\mathrm{L}) \\
7 & (\mathrm{PI}-\mathrm{L}) \\
10 & (\mathrm{PII}-\mathrm{L}) \\
13 & (\mathrm{PI}-\mathrm{L})\end{aligned}$ & $\begin{array}{l}\text { vocational training or GED } \\
\text { WIN program } \\
\text { low-cost housing } \\
\text { single mothers' support group }\end{array}$ & $\begin{array}{l}88 \% \\
85 \% \\
96 \% \\
85 \%\end{array}$ \\
\hline $\begin{array}{l}\text { II } \\
\text { (Direct } \\
\text { Service-- } \\
\text { More than } \\
9 \text { years } \\
\text { experience }\end{array}$ & $\begin{aligned} 2 & (\mathrm{PI}-\mathrm{C}) \\
4 & (\mathrm{PI}-\mathrm{L}) \\
7 & (\mathrm{PI}-\mathrm{L}) \\
10 & (\mathrm{PII}-\mathrm{L}) \\
13 & (\mathrm{PI}-\mathrm{L}) \\
14 & (\mathrm{PII}-\mathrm{L})\end{aligned}$ & $\begin{array}{l}\text { feelings about herself } \\
\text { vocational training or GED } \\
\text { WIN program } \\
\text { low-cost housing } \\
\text { single mothers' support group } \\
\text { advocate with landlord and } \\
\text { welfare department }\end{array}$ & $\begin{array}{l}79 \% \\
79 \% \\
83 \% \\
97 \% \\
86 \% \\
79 \%\end{array}$ \\
\hline
\end{tabular}


work motivation (Paradigm I- Liberal) and using mental health and rehabilitation centers to upgrade the poor (Paradigm I-Conservative).

\section{DATA ANALYSIS: PART II}

The hypothetical situation presented in Part II of the questionnaire was as follows:

As a caseworker, you receive the case of a 20-year-old black mother of two children, ages two and five. She has never been married and is on welfare. Melba dropped out of high school when she got pregnant at age 15 . She has no job skills and presently lives in a shabby two-room apartment in the ghetto of a large midwestern city. She is two months behind in her rent and has received notice of eviction. Feeling there is nowhere she can go, Melba is depressed and immobilized by her present situation.

This situation was followed by a list of 16 statements having to do with actions the caseworker might take in working with this client. ${ }^{37}$ The responses to the situation were analyzed in terms of whether the statements were seen as highly relevant, somewhat relevant, somewhat irrelevant, or highly irrelevant. For the purposes of this study, "highly relevant" and "somewhat relevant" were regarded as "agree" responses, and "somewhat irrelevant" and "highly irrelevant" were regarded as "disagree" responses. Again, the object was to assess how many "agree" responses there were, on the average, within each attitudinal category. This would indicate which category or categories the attitudes of the sample tended to fit into.

\section{Hypotheses}

The hypotheses made about the responses to Part II of the

${ }^{37}$ See Appendix A. 
questionnaire, dealing with actions a caseworker would take in working with a poor client, were as follows:

1. The respondents will be more likely to agree with Paradigm I (individual change) statements than Paradigm II (institutional change) statements.

2. The majority of respondents will agree with more liberal statements (in either Paradigm I or Paradigm II) than conservative or radical statements combined.

3. The majority of individual items with high agreement rates (over 75 per cent) will fall into the two "liberal" categories.

$\underline{\text { Results }}$

The respondents agreed with items in Part II of the questionnaire in 60 per cent of all cases. ${ }^{38}$ An analysis of the "agree" responses indicates that the respondents were somewhat more likely to agree with Paradigm I than Paradigm II statements. The highest mean number of "agree" responses was in the liberal Paradigm I category (3. 33 out of a possible maximum of four agree responses). The lowest mean number of "agree" responses was in the radical Paradigm II category (1.24 out of a possible four). These results support the hypothesis that, in working with poor clients, the respondents would be somewhat more likely to consider actions involving individual change or self-betterment on the part of a client, rather than considering actions directed at broad social change.

As in Part I. the data were analyzed in terms of the percentage of respondents agreeing with more Paradigm I than Paradigm II

${ }^{38}$ See Table III, p. 33. "Part II" of the questionnaire refers to the direct service version. The data from the planning version were not analyzed due to the small sample size $(n=9)$. 
statements, the percentage agreeing with more Paradigm II than Paradigm I statements, and the percentage agreeing with an even number of each. Again, the object was to get an overall picture of which paradigm the respondents' attitudes tended to fit into, without breaking down into the sub-categories.

It was found that a slim majority (58 per cent) agreed with more Paradigm I statements, while 20 per cent agreed with more Paradigm II statements and 22 per cent were evenly divided between the paradigms. 39 This finding supports the hypothesis that the direct service respondents were somewhat more likely to focus on actions oriented toward individual change in working with a poor client. However, almost half ( 42 per cent) of these respondents were at least as likely to support social change-oriented actions as individual change-oriented actions.

As in Part I, the data were analyzed to see whether the majority of respondents agreed with more liberal statements (in either paradigm) than conservative or radical statements combined. Again it was found that a solid majority ( 80 per cent) of the respondents agreed with more liberal than either conservative or radical statements, 40 indicating a "moderate" approach to conceptualizing and dealing with problems of poverty.

An analysis was done of the "agree" response rates of individual items to see which items had high agreement rates of 75 per cent or

$$
\begin{aligned}
& { }^{39} \text { See Table V, p. } 36 . \\
& { }^{40} \text { See Table VI, p. } 39 .
\end{aligned}
$$


more, and which attitudinal categories these items represented. The hypothesis that the highest consensus of agreement would be on items in the liberal categories was supported by the data. In Part II of the questionnaire, all five items with high "agree" rates belonged in the liberal categories of attitudes. ${ }^{41}$ Two of these were in Paradigm II and three in Paradigm $I$.

There was only one item with a high disagreement rate (over 75 per cent of respondents disagreeing) in Part II. ${ }^{42}$ This item had to do with suggesting that a poor client read books that were critical of American society (Paradigm II-Radical).

Data Analysis: Part II, According to Years of Experience

A further analysis was done of Part II, breaking the respondents into two groups based on more or less than nine years of experience in the field. Arangio found more than nine years of experience to be a variable associated with an individual change orientation, and less than nine years of experience to be associated with an organizational or institutional change orientation. It must be pointed out that "years of experience" was only one of several variables he found to be related to differing ideological orientations toward social problems. However, it was felt that an analysis of any one of these variables might corroborate Arangio's findings. The writer originally intended to apply this analysis, as well as a breakdown by sex of respondent, to both parts of the questionnaire. These efforts were thwarted by numerous problems

$$
\begin{aligned}
& { }^{41} \text { See Table VII, p. } 40 . \\
& { }^{42} \text { See Table VIII, p. } 45 .
\end{aligned}
$$


TABLE VIII

ITEMS WITH HIGH DISAGREEMENT RATE

\begin{tabular}{|c|c|c|c|}
\hline Part & $\begin{array}{l}\text { Item \# \& } \\
\text { Category }\end{array}$ & Description & $\begin{array}{c}\% \text { of } \\
\text { Respondents } \\
\text { Disagreeing } \\
\end{array}$ \\
\hline I & $\begin{array}{l}6(\mathrm{PI}-\mathrm{L}) \\
8(\mathrm{PI}-\mathrm{C})\end{array}$ & $\begin{array}{l}\text { welfare/work motivation } \\
\text { mental health and } \\
\text { rehabilitation centers }\end{array}$ & $\begin{array}{l}81 \% \\
91 \%\end{array}$ \\
\hline $\begin{array}{l}\text { II } \\
\text { (Direct } \\
\text { Service-- } \\
\text { Total } \\
\text { group) }\end{array}$ & I 5 (PII-R) & $\begin{array}{l}\text { critical books on } \\
\text { American society }\end{array}$ & $75 \%$ \\
\hline $\begin{array}{l}\text { II } \\
\text { (Direct } \\
\text { Service-- } \\
\text { Less than } \\
9 \text { years } \\
\text { experience) }\end{array}$ & & $\begin{array}{l}\text { no items with disagreement } \\
\text { by } 75 \% \text { or more of } \\
\text { respondents }\end{array}$ & \\
\hline $\begin{array}{l}\text { II } \\
\text { (Direct } \\
\text { Service-- } \\
\text { More than } \\
9 \text { years } \\
\text { experience) }\end{array}$ & I 5 (PII-R) & $\begin{array}{l}\text { critical books on } \\
\text { American society }\end{array}$ & $76 \%$ \\
\hline
\end{tabular}


with computer programming and rapidly approaching deadlines.

The hypothesis postulated here is that those respondents with more than nine years of experience in the field of social work will tend to agree with more statements toward the conservative or Paradigm I end of the continuum of attitudes than those respondents with less than nine years of experience in the field.

$\underline{\text { Results }}$

The data provided some support for this hypothesis. Although the difference between the two groups does not appear to be statistically significant, it is consistent with Arangio's findings. In looking at the mean number of agree responses per category, the pattern for the two groups was the same as for the total group in Part II. ${ }^{43}$ The highest mean number of "agree" responses was in the liberal Paradigm I category and the lowest in the radical Paradigm II category in all cases. However, the group with more than nine years of experience showed slightly higher mean numbers of "agree" responses in the Paradigm I categories than the group with less than nine years of experience.

In looking at the percentage of respondents agreeing with more Paradigm I than Paradigm II statements (and vice versa), the difference between the two groups is more pronounced. Among the total group, 58 per cent of the respondents agreed with more Paradigm I than Paradigm II statements. ${ }^{44}$ Among the group with less than nine years of experience, 42 per cent agreed with more Paradigm I than Paradigm

\footnotetext{
${ }^{43}$ See Table IV, p. 35. ${ }^{44}$ See Table V, p. 36.
} 
II statements. For the group with more than nine years of experience, this figure jumped to 72 per cent. These findings support the hypothesis that social workers with more than nine years of experience in the field tend to focus on individual change-oriented actions in working with poor clients more than do those with less than nine years of experience.

In analyzing the percentage of respondents that agreed with more liberal statements (in either paradigm) than radical or conservative statements (combined), there is, again, a slight difference between the two groups based on years of experience. In all cases, a majority of respondents agreed with more liberal than radical or conservative statements. 45 For the total group, the figure was 80 per cent. For the group with less than nine years of experience, the figure was 73 per cent agreeing with more liberal statements. For the group with more than nine years of experience, the figure was 86 per cent. Again, these results corroborate Arangio's findings.

In analyzing which individual items had high "agree" rates (over 75 per cent of the respondents agreeing), all of these items belonged in the liberal categories when looking at the responses of the total group. When breaking the group down according to years of experience, this finding remained the same for the group with less than nine years of experience. 46 However, the group with more than nine years of experience also had a high agreement rate on one conservative item,

\footnotetext{
${ }^{45}$ See Table VI, p. 39. ${ }^{46}$ See Table VII, p. 40.
} 
having to do with focusing on the client's feelings about herself in order to get to the root of her problems.

In Part II of the questionnaire there was only one item with a high disagreement rate. 47 This was the item having to do with suggesting that the client read books critical of American society (Paradigm II-Radical). In breaking the respondents into two groups based on years of experience, it was found that this item had a disagreement rate of over 75 per cent only among the group with more than nine years of experience.

Although the differences in responses between the two groups based on more or less than nine years of experience do not appear to be statistically significant, they are in every case consistent with Arangio's findings. They support the hypothesis that social workers with more than nine years of experience in the field tend to focus on approaches geared toward individual change or self-betterment, rather than organizational or institutional change more than do those workers with less than nine years of experience in the field.

Conclusions

Based on the preceding data, it can be concluded that the social workers studied were more likely to believe in structural or institutional change within society than to try to carry those beliefs into action. However, direct service workers were found to be more likely to focus on individual change and growth than on organizational or institutional change in their work. There was a slight tendency for

${ }^{47}$ See Table VIII, p. 45. 
direct service workers with more than nine years of experience in the field to be more conservative in their orientation to service than those with less than nine years of experience. In other words, they were even more likely than those with less than nine years of experience to hold individuals or groups of poor people directly or indirectly responsible for their poverty, rather than seeing the primary causes in the organizations and institutions of society. Likewise, they were slightly more likely than those with less than nine years of experience to place the burden of solving problems of poverty on the poor themselves, rather than calling for structural changes within social systems.

The social workers studied were found to be predominantly "liberal, "rather than "conservative" or "radical" in their beliefs and probable actions, whether in the area of individual (Paradigm I) or social (Paradigm II) change. They tended to see individual responsibility for the causes and solutions to poverty as having to do mainly with lack of opportunity or awareness of opportunities, and stigma or prejudice. They did not tend to find the poor directly "at fault," or see them as inherently inferior to the mainstream of society. Solutions were seen primarily in helping the poor to take advantage of existing opportunities or providing more opportunities for them to better their situations.

In thinking about social change on the structural level, the sample tended not to look at society as a whole, to see how its various institutions interrelate and contribute to the maintenance of poverty. Rather, they were inclined to focus on specific organizations and areas of need, such as developing more vocational training programs and job 
opportunities, or reforming the welfare system. This is what the study has defined as "liberal thinking."

\section{Commonly Agreed-on Causes and Solutions}

The most commonly agreed-on causes of poverty were lack of job opportunities, racial prejudice, lack of education and vocational training, lack of awareness of legal rights to available benefits, the stigma and dehumanization of public welfare (which keeps many eligible people off the rolls), and government's tendency to cater to large corporations, putting "profits before people."

Among the direct service respondents, the most commonly agreed-on courses of action in dealing with a young, black welfare mother were encouraging her to take advantage of the WIN program (whereby she could work and still stay on welfare, receiving partial benefits), helping her find low-cost public housing, encouraging her to get into a GED or vocational training program, encouraging her to join a single mothers' support group, and acting as her advocate in dealing with her landlord and the welfare department. The respondents with over nine years of experience in the field also had a high rate of agreement on helping her focus on her feelings about herself to "get to the root of the problem."

Statements about poverty most commonly disagreed with were that being on welfare destroys work motivation, and that mental health and rehabilitation centers are the answer to solving poverty. In doin? casework, the action most commonly disagreed with was suggesting that the poor client read books critical of American society, in order to raise consciousness, while at the same time improving reading 
skills. The hypothesis that the most commonly agreed-on statements about poverty would be predominantly in the liberal categories (in both paradigms) was supported by these findings.

Limitations of the Study

The most obvious 1 imitation of the study is that the sample was not random; therefore, the results cannot be generalized. The study is descriptive of the sample alone, and any attempt to apply the results to social workers in general would be merely speculative.

The conclusions arrived at are possible indicators of the sample's attitudes about the causes of poverty and the solutions to poverty. However, the findings of the study rest on the assumption that the instrument used was able to measure the attitudes it was designed to measure. This assumption was not supported by the results of a factor analysis of the questionnaire. Except for the Paradigm I items in Part II, the factor analysis did not verify that the respondents perceived the same common factors within each category of items as was intended. The results of the study are interesting in a descriptive sense, in terms of the items the respondents did and didn't agree with. However, the categorization of their responses remains essentially hypothetical, bearing in mind the results of the factor analysis.

\section{Feedback From Respondents}

The respondents themselves provided valuable feedback on the questionnaire through comments included in their returns. The following is a summary of their major criticisms. Several respondents 
stated that they were uncomfortable with the "forced choice" situation.

This aspect was considered in designing the instrument. It was feared that if a "maybe" or "uncertain" response option were provided, many respondents would choose this option in response to difficult items and the information gathered would be diminished. The respondents were cautioned in the cover letter 48 to "agree" with an item only if they could agree with all parts of it. Still, it must be considered that the responses gathered may in some cases be only a rough approximation of the respondents' beliefs and attitudes, since they were not given the option of a qualified response.

Several members of the sample commented that they had difficulty with some of the items because of their complexity or their generality. In some cases they agreed with part of a statement but not all of it. In other cases they felt they "needed more information" about either the situation they were asked to place themselves in, or about the particular statement they were responding to. Many respondents felt a need to qualify their answers, either quantitatively (i.e., "sometimes, depending on the situation") or qualitatively (actually modifying the statement to agree with their point of view).

Other comments included that the items were too "restrictive," too "simplistic," or that (in Part II) the actions chosen would have to depend on "what Melba wanted." A few respondents had trouble understanding some of the terms used, such as "disadvantaged" and "manpower" programs.

${ }^{48}$ See Appendix A. 
One respondent, who declined to answer the questionnaire, directly criticized the study design, commenting,

The statements imply that all social workers have chosen or choose between two distinct descriptions of social work practice. . there is validity in all the statements. . which to emphasize depends on social, economic, and political conditions. The design. . . unfairly traps social workers into a position they may not hold.

It is felt that this respondent was making some unfounded assumptions about the intentions of the study. The findings show that the social workers studied were not forced into one of two distinct positions (either Paradigm I or Paradigm II). The intention of the study was to assess whether their attitudes tended to lean in one direction or the other, not necessarily to the exclusion of either. In any case, it is of value, in conducting a study, to know how the instrument used is perceived by respondents.

$\underline{\text { Reactions to the Is sues Studied }}$

Some members of the sample commented on the content of items in the questionnaire, in addition to the format. One respondent felt that some of the statements were biased and judgmental (i.e., Part II, No. 2, which implies that the root of Melba's problems was her feelings about herself). It is suspected that the respondent agreed with part but not all of the statement.

Another respondent felt a need to differentiate between actions geared toward immediate needs and those geared toward post-crisis help in Part II. The instrument did not incorporate such a distinction, although it did allow for responses on both levels.

Still another respondent commented that he/she didn't like the 
"blame-laying" flavor of Part I; that the focus should be on "constructive solutions" instead. This attitude would seem to deny the importance of understanding the causes of poverty in order to devise adequate solutions. However, it can again be emphasized that the respondent's perception of and reaction to the questionnaire is an important consideration in conducting research.

Other comments included that "important determinants" were omitted in Part I (which determinants was not stated); and that both the "right actions" and the "right attitudes" were necessary in trying to solve poverty.

In conclusion, it is felt that the respondents' comments and feedback on the questionnaire were an important source of information in addition to the responses themselves. Not only did they provide additional information about the respondents' attitudes about poverty, but the criticisms made would be important considerations in creating designs for further research in this area. 


\section{CHAPTER V}

\section{SUMMARY AND RECOMMENDATIONS}

The purpose of the study here was to assess the attitudes of a sample of local social workers about poverty. The focus was on their beliefs and attitudes about poverty's causes and solutions. The primary reason for doing this study was that little research has been done to date on this topic. If one accepts the premise that how poverty is conceptualized as a social problem will determine what solutions are attempted, such research can be valuable.

A second reason for doing the study was to provide information to the Portland State School of Social Work about the attitudes its students are encountering in their field work. The study sample consists of the school's field instructors for the academic year 1975-76. This group is comprised of social workers working in various kinds of agencies and positions in and around the Portland metropolitan area. They supervise social work students two days a week. It was felt that this information might be useful to the school in evaluating, developing, or modifying curriculum.

A review of relevant literature was conducted (see Chapter II). It was found that, although many studies have been done during the last decade about the poor, few have been done on attitudes about poverty held by those professionals who work with the poor. Arangio (1970) did a study similar to this one. He focused on the attitudes of professional social workers toward "change targets, goals, and tactics." Using a 
random sample, he attempted to discern whether social workers were more strongly oriented toward individual change or institutional change. His conclusions were that most social workers were "strongly oriented toward individual change," disagreeing with tactics of a controversial nature on both the individual and institutional levels.

The study conducted here is based in part on Arangio's work. The instrument used was a questionnaire, described in detail in Chapter III. The questionnaire was divided into two parts. Part I was to assess attitudes about poverty's causes and solutions on the theoretical level. Part II was to assess actions the respondents would take in dealing with problems of poverty in a professional capacity.

The questionnaire was designed in the context of a theoretical framework borrowed from Warren (1971). As described in Chapter II this framework consists of two "paradigms, " or contexts in which to understand poverty. The Paradigm I perspective maintains that poverty has its roots in the deficiencies of individuals; that the institutions of society are basically sound, and that poor individuals must adapt or change if poverty is to be eliminated. The Paradigm II perspective maintains that the causes of poverty lie in structural inequities within our social institutions, such as the economic system. According to this point of view, poverty is actually a symptom of structural defects and cannot be solved until social changes are achieved on the institutional level.

For the purpose of assessing the attitudes of the study sample, these two major categories were each broken into two sub-categories. This was done in order to allow for a range of views, rather than 
trying to fit attitudes into a strictly "either-or" framework. The subcategories distinguished between a liberal, "middle-of-the-road" position and a more extreme (either conservative or radical) position within each paradigm (described in Chapter III).

It was hypothesized that the attitudes of the social workers studied would fall predominantly into the liberal or "middle" range of views, extending into both paradigms. In other words, they would tend to attribute the causes of poverty to social factors without taking a comprehensive look at society to see how its various institutions interrelate to contribute to poverty. They would tend to focus on individualized or practical objectives in dealing with poor clients, on either the casework or the planning level. They would not tend to blame poor clients directly for their poverty but would still place ultimate responsibility for change and self-improvement on their shoulders.

The findings supported this hypothesis. The bulk of the statements the sample agreed with fell into the two "liberal" categories.

In Part I of the questionnaire, dealing with poverty on the abstract level, the highest rate of agreement was found with statements in the liberal Paradigm II category. This means that the social workers studied were likely to conceptualize poverty as a social problem being perpetuated by inadequate, inefficient, or dehumanizing organizations that purport to help the poor. Other commonly agreedon factors were lack of opportunity for training or jobs, racial prejudice, lack of awareness of legal rights to existing benefits, and the failure of government's priorities to favor human needs. 
In Part II of the questionnaire, dealing with actions the respondents would take in working with a black welfare mother, the highest rate of agreement was found with statements in the liberal Paradigm I category. This means that the respondents tended to think in terms of how the client could improve her own situation by taking advantage of available opportunities. The worker's role was to assist her in doing this, and to act as her personal advocate if necessary. Actions directed toward consciousness-raising and broad social change related to the client's problems were not seen to be as relevant as practical, individualized solutions.

It was also found that the direct service respondents with more than nine years of experience in the field tended to respond slightly more toward the conservative end of the scale of attitudes than those with less than nine years of experience. The above results are consistent with Arangio's findings.

At this point it must be mentioned that the findings of this study rest on the assumption that the instrument used was able to measure the attitudes it was designed to measure. A factor analysis of the data did not generally support this assumption. Except for the Paradigm I statements in Part II of the questionnaire, there is no empirical evidence to show that the respondents perceived the intended common factors among the items within each attitudinal category. Although the responses provide descriptive information in terms of the content of beliefs and attitudes, the categorization of these beliefs and attitudes remains essentially hypothetical. However, it is significant that the Paradigm I statements in Part II were perceived to have common 
factors as intended. They also showed a higher rate of agreement than the Paradigm II statements in this section.

The primary limitation of the study lies in the fact that the sample was not random and, therefore, the results cannot be generalized. Other limitations stem from the structure and content of the instrument. As previously discussed, it was not verified that the questionnaire was able to measure the attitudes it was designed to measure. Also, feedback from the respondents indicated that they experienced some difficulty in dealing with a "forced-choice" situation in which they were not given an "undecided" option. Therefore, it must be assumed that the data gathered may only roughly approximate the sample's beliefs and attitudes, not having allowed for qualification of responses. However, important, albeit difficult-to-quantify information was gathered from the spontaneous comments of the respondents. This had to do mainly with their perceptions of and reactions to the questionnaire and the study, providing information to consider in doing further research in this area.

The need for further and more extensive research exploring beliefs and attitudes about poverty became evident in undertaking this study. Social work is the primary profession dealing with problems of poverty. Social workers basically lack the power to change the conditions that perpetuate poverty in America. This fact seems to build a fairly high level of frustration and/or avoidance of the problem into the profession. However, by avoiding gaining an understanding of and attempting to deal on some level with problems of poverty, social workers may inadvertently be helping to perpetuate the conditions they 
hope to eliminate. Therefore, it is important that social workers gain a comprehensive understanding of poverty in America and that they share this understanding with their poor clients; the premise being that a dequate understanding must precede any effective action. Further empirical research about the phenomenon of poverty, its causes and maintenance, and about the beliefs of professionals regarding poverty, will promote such understanding.

In this light, I commend and encourage the Portland State School of Social Work's student, faculty, and administrative efforts to incorporate into the curriculum courses that deal with these issues. I recommend that efforts at gaining an understanding of poverty and related social problems through coursework and symposiums continue. I recommend that there be an emphasis on how social workers can organize to begin, step by step, to deal with the se issues in light of a comprehensive societal understanding. I recommend the continuance of efforts to integrate or connect the concrete with the abstract, the human and personal with the political and theoretical; the immediate situation (casework) with long-range goals (planning).

Last of all, I wish to say that social workers can serve as prophets who seek to gain and promote understanding; they can serve as activists or instigators, but that they cannot and should not be expected to shoulder society's burden of poverty alone. Assuming responsibility without adequate power can lead to self-defeat. Assuming power without adequate responsibility perpetuates oppression. Change in the balance of power is a necessary part of the solution. 


\section{A SELECTED BIBLIOGRAPHY}

Alston, John P. and Imogene Dean, "Socioeconomic Factors Associated with Attitudes Toward Welfare Recipients, "Social Service Review, 46:1 (March 1972), pp. 13-23.

Arangio, Anthony Joseph, "Individual Change or Institutional Change: Attitudes of Professional Social Workers Toward Change Targets, Goals, and Tactics," Ph. D. dissertation (Tulane University, 1970).

Cameron, Colin, Attitudes of the Poor and Attitudes Toward the Poor: An Annotated Bibliography, Institute for Research on Poverty (Madison: University of Wi sconsin, 1975).

Edelman, Murray, "The Political Language of the Helping Professions," Politics and Society, 4:3 (1974), pp. 295-310.

Epstein, Irwin, "Social Workers and Social Action: Attitudes Toward Social Action Strategies," Social Work, 13:2 (April, 1968), pp. $101-108$.

Everson, Bradford L., "Value Orientation in Relation to Emphasis in the Process of Diagnosing the Family in State of Crisis, "MSW thesis (Portland: Portland State University, 1969).

Feagin, Joe R., "America's Welfare Stereotypes," Social Science Quarterly, 52:4 (March, 1972), pp. $921-933$.

Goodwin, Leonard, "How Suburban Families View the Work Orientations of the Welfare Poor: Problems in Social Stratification and Social Policy," Social Problems, 19:3 (Winter, 1972), pp. 337 348 .

Grosser, Charles F., "Perceptions of Professionals, Indigenous Workers and Lower-Class Clients," DSW dissertation (Columbia University, 1965).

James, Dorothy Buckton, Poverty, Politics, and Change (Englewood Cliffs, New Jersey: Prentice-Hall, 1972).

Lauer, Robert H., "The Middle Class Looks at Poverty, "Urban and Social Change Review, 5:1 (Fall, 1971), pp. 8-10.

Lee, Stephen D., "Social Class Bias in the Diagnosis of Mental Illness," Ph. D. dissertation (University of Oklahoma, 1968). 
Livingston, Samuel A., "Simulation Games and Attitude Change: Attitudes Toward the Poor," Center for the Study of Social Organization of Schools (Johns Hopkins University, April, 1970), $14 \mathrm{pp}$.

Long, Samuel, and Ruth Long, "Teacher-Candidates' Attitudes Regarding Poverty and the Disadvantaged, "Urban Education, 7:4 (January, 1973), pp. 371-382.

Lumer, Hyman, Poverty: Its Roots and Its Future (New York: International Publishers, 1965).

McDonald, Archie D., "Attitudes Toward the Legitimacy of Public Intervention on Behalf of Poor Persons: Correlates and Consequences of Three Generations, "DSW dissertation (University of Southern California, 1971).

Mills, C. Wright, "The Professional Ideology of Social Pathologists," American Journal of Sociology, 49:2 (September, 1943), pp. 165180.

Dasteur, Alfred B., "The Social Class Origins of Black Counselors and their Attitudes Toward Disadvantaged Youth, "Ph. D. dissertation (Northwestern University, 1971).

Podell, Lawrence, "Fertility, Illegitimacy and Birth Control," The Center for Social Research (New York: The City University of New York, 1968).

Podell, Lawrence, "Help Has No Structure in the Troubled World of welfare," Human Needs, 1:9 (March, 1973), pp. 7-8.

Poverty and Human Resources: Abstracts and Survey of Current Literature (Ann Arbor: Institute of Labor and Industrial Relations, University of Michigan, Wayne State University, vol. 5, 1970).

Pratt, Lois, "Optimism-Pessimism About Helping the Poor with Health Droblems," Social Work, 15:2 (April, 1970), pp. 29-33.

Robinson, John P., Jerrold G. Rusk, and Kendra B. Head, Measures of Political Attitudes, Survey Research Center, Institute for Social Research (Ann Arbor: University of Michigan, 1968).

Robinson, John P., and Phillip R. Shaver, Measures of Social Psychological Attitudes (Appendix B to Measures of Political Attitudes), Survey Research Center, Institute for Social Research (Ann Arbor: University of Michigan, 1969).

Ryan, William, Blaming the Victim (New York: Vintage Books, 1972). 
Rytina, Joan Huber, William H. Forum, and John Pea se, "Income Stratification Ideology: Beliefs About the American Opportunity Structure, "American Journal of Sociology, 75:4 (January, 1970), pp. 703-716.

Schwartz, William, "Private Troubles and Public Issues: One Job or Two?" Lindeman Memorial. Lecture, National Conference on Social Welfare (New York City, May 28, 1969).

Steiner, Gilbert Y., The State of Welfare (Washington, D. C.: The Brooking Institution, 1971).

Tussing, A. Dale, Poverty in a Dual Economy (New York: St. Martin's Press, 1975).

Vail, Susan, "The Effects of Socioeconomic Class, Race, and Level of Experience on Social. Workers' Judgments of Clients, "Smith College Studies in Social Work, 40:3 (June, 1970), pp. $\overline{236-246 .}$

Warren, Roland, "The Sociology of Knowledge and the Problems of the Inner Cities, "Social Sciences Quarterly, 52:3 (December, 1971), pp. 469-492. 


\section{APPENDIX A}

\section{QUESTIONNAIRE}

\section{Dear PSU Field Instructor:}

As a second year MSW candidate at Portland State School of Social ${ }^{W T}$ ork, I am doing research for my practicum on the views of social work practitioners regarding poverty, its causes, how to help poor people, and how to fight poverty on both the individual and social levels. My study may be useful to the school in providing information about the social work values and viewpoints that students are exposed to in the field.

Answering the enclosed questionnaire will take about half an hour of your time. I have conveniently provided a separate answer sheet (the last page) which may be detached and filled in along side the que stionnaire as you go through the items. I realize that the questionnaire may force some difficult choices, but this is necessary in order to measure attitudes. If you find items that you cannot agree with as they are stated, then please put them into a "disagree" or "irrelevant" category. Also, please feel free to note any important options that you feel should have been included on the back of the answer sheet.

Instructions for filling in the answer sheet are included on the sheet and at the beginning of each section, starting on the next page. Please be sure to fill in the identifying information on the answer sheet - - this will be needed in analyzing my data. It will be kept confidential. Also, feel free to make any comments about your reaction to the questionnaire on the reverse side.

Enclosed is a self-addressed, stamped envelope for your convenient return of the answer sheet. I will need your response by February in order to stay on schedule.

Your cooperation and help are greatly appreciated!

Sincerely,

Trudy Hussmann 1804 SE Pine Street

Portland, Ore. 97214 
Part I

You are asked to give a guest lecture for a college course entitled "Introduction to Social Work" on the subject "Poverty in America: Its Causes and Cures."

Of the following list of statements regarding beliefs and actions in relation to poverty, evaluate them in terms of whether you:

A. Agree with them and would include them in your talk.

B. Agree with them but find them irrelevant to the issue and therefore wouldn't include them in your talk.

C. Disagree with them and would include them in your talk in order to refute them.

D. Disagree with them and therefore would not include them in your talk.

1. Teaching poor children to be able to defer need gratification will be essential in helping them to rise out of poverty.

2. If our nation had a government-planned economy, wages and salaries would be fairer, jobs more steady, and we would have less unemployment and poverty.

3. The cycle of poverty is difficult to break because the attitudes and feelings of the poor (i.e., fatalism and helplessness) are passed on from generation to generation, causing a vicious circle that can be broken only by highly motivated individuals.

4. Lower class people share society's general success goals, but lack legitimate opportunities for achieving them; therefore, social workers must encourage the development of more job opportunities.

5. Poverty and unemployment will not be eradicated as long as we have a free enterprise economy, for they are necessary for its functioning (by keeping wages down and providing cheap labor).

6. Public assistance gets people used to not having to work for a living and makes it harder to motivate them for future employment.

7. A disproportionate number of minority people are poor in America because of the prejudicial attitudes of many white Americans.

8. If there were enough mental health facilities and rehabilitation centers to reach all poor and disadvantaged people, our society could deal effectively with the problem of poverty. 
9. The development of an effective poor people's labor movement would do more to advance the war on poverty than any measure that has been taken by our existing government.

10. As a nation we need to invest in a massive campaign of education and vocational training for the poor if we are ever going to make a dent in poverty.

11. A crucial reason this country hasn't been able to solve poverty is because the government's first allegiance is to large corporations who put profits before people.

12. Encouraging people to move out of "poverty pockets" (i.e., ghettos) so that they are not surrounded by a materially and culturally impoverished environment will help them to break the cycle of poverty in their lives.

13. One factor that works to perpetuate poverty in this country is the general lack of acceptance of or desire for birth control among poor women, resulting in large families that are difficult to support.

14. The general public isn't very aware of its legal rights and this prevents many people who are eligible for some kinds of benefits or programs from taking full advantage of the se opportunities.

15. Improved and more efficient manpower programs for disadvantaged people would bring us closer to solving the problems of poverty.

16. Another factor contributing to poverty is that many people who might be eligible for welfare don't apply because of the stigma and dehumanizing treatment involved. 
Part II

As a caseworker, you receive the case of a 20-year-old black mother of two children, ages two and five. She has never been married and is on welfare. Melba dropped out of high school when she got pregnant at age 15. She has no job skills and presently lives in a shabby two-room apartment in the ghetto of a large midwestern city. She is two months behind in her rent and has received notice of eviction. Feeling there is nowhere she can go, Melba is depressed and immobilized by her present situation.

Of the following statements pertaining to evaluation of situations like Melba's and deciding how they could best be approached, please group them according to whether you find them:

A. Highly relevant and you would be sure to pursue or support this kind of approach.

B. Somewhat relevant and you would probably pursue or support this kind of approach.

C. Somewhat irrelevant and you probably wouldn't pursue or support this kind of approach.

D. Highly irrelevant with your beliefs and you certainly wouldn't pursue or support this kind of approach.

1. I would refer Melba to the local Welfare Rights organization so that she could learn her rights as a welfare client, to take advantage of opportunities for improving her situation.

2. I would focus on Melba's feelings about herself, so we could get to the root of the problems she finds herself in.

3. I would present Melba the alternative of participating in a demonstration being planned to protest the inadequacy of welfare payments.

4. I would encourage Melba to get into some kind of vocational training or GED program with the goal that she could eventually get off welfare.

5. I would acknowledge Melba's helpless depression as understandable in her situation and would try to channel it into anger at the social conditions that contribute to her predicament.

6. I would refer Melba to the agency's money management counselors, who could help her learn to plan for the future and avoid getting behind in her rent. 
7. I would encourage Melba to take advantage of the WIN program, whereby she could work and still stay on welfare, raising her income considerably.

8. In acting as Melba's advocate, I would write to the state director of public welfare regarding the financial problems of welfare clients.

9. I would help Melba examine the "lifescript" that may be stopping her from getting off welfare, as a starting point for on-going counseling.

10. I would encourage Melba to explore alternatives that may be open to her, that she may not be aware of, such as being eligible for low-cost housing.

11. I would organize a group of social workers and clients with similar problems around the is sue of child care services to take some collective action at the state capitol.

12. If Melba were open to counseling beyond the crisis situation, I would focus on her relationships with men in order to help her break the pattern of having illegitimate, unsupported children.

13. I would encourage Melba to get involved in a single mothers' group, to give her support and to discuss ways of improving their situations.

14. I would act as Melba's advocate and make sure that her landlord didn't treat her unfairly and that she got courteous, attentive treatment at the welfare department, walking her through the agency if necessary.

15. I would suggest some critical books on American society and the welfare system for Melba to read, in order to broaden her awareness, while at the same time improving her reading skills.

16. I would suggest to Melba that perhaps enrolling in some courses at the local community college (for which a high school diploma is not required) would give her a chance to learn and do something interesting. 
Part II

As an esteemed and experienced planner, you are asked to make policy recommendations to the state public welfare planning board regarding a program they are developing to combat disorganization and breakdown among welfare families.

Of the following statements regarding policy and the beliefs upon which it rests, evaluate them in terms of whether you find them:

A. Highly relevant and you would be sure to recommend this policy and/or state the belief upon which it rests.

B. Somewhat relevant and you would probably recommend this policy and/or state the belief upon which it rests.

C. Somewhat irrelevant and you probably wouldn't recommend this policy and/or state the belief upon which it rests.

D. Irrelevant or in disagreement with your beliefs and you wouldn't recommend this policy or state the beliefs upon which it rests.

1. I would urge the board to lobby in Congress for the abolition of our present welfare system and the adoption of an adequate guaranteed annual income, since the existing system inherently undermines family stability.

2. Expanding social services through public welfare to include parent education classes and family therapy would provide a valuable source of support to unstable families, by helping to strengthen family relationships.

3. I would argue that any attempts to stabilize welfare families were futile unless the payments they received were realistic for economic survival in this day.

4. Developing a "Welfare Hotline" service operating on a round-theclock basis could help forestall many family crises by providing immediate counseling and/or advice.

5. I would propose developing within the institution a department of "client advocates" who would intervene on behalf of individual clients in any problem situation within the community, thereby reducing stress on families in coping with the environment.

6. I would urge the state to recommend to the federal government that it embark on a massive program of reordering its priorities so that human needs were placed at the top of the list. 
7. A law should be enforced whereby welfare mothers who continue to have illegitimate children will be required to undergo sterilization if they want to keep receiving assistance.

8. I would recommend the allocation of state and federal funds to community social service agencies for the purpose of their developing special programs for welfare families, aimed at promoting and enhancing family stability.

9. I would propose the development of an inter-agency coordinating council, so that the various community agencies providing social services to families could coordinate and balance each other's efforts.

10. I would propose the development of a medical counseling and referral service for welfare clients, since poor people tend to have more health problems than other segments of society, and poor physical health can often affect the emotional climate and stability of relationships within families.

11. I would advocate the creation of a task force to research the state of the modern family, including all its variations, and the historical development of social stresses that impinge upon family stability and functioning.

12. I would recommend that efforts be focused on expanding job training programs and increasing training allowances, as a way to enhance potential family stability.

13. A program should be developed to remove children from the homes of welfare families who are not able to stay together as a unit, so that the children won't grow up in a highly unstable situation.

14. I would recommend a campaign to de-stigmatize welfare by such measures as a liberalization of means test procedures and public promotion of the necessity and benefit of public assistance programs.

15. I would urge the board to look at how factors outside of, but related to, the welfare system (such as racist practices of hiring and firing) affect family stability.

16. We should institute a law that imposes an economic sanction on the welfare family if the male head of the household leaves (if he was with the family when they initially applied for aid), as an incentive to keep him in the home. 
ANSWER SHEET

Age

Sex

Position

Type of agency

Years of experience in the field

Instructions: As you evaluate each statement in a section, please write its number in the appropriate box A, B, C, or D.

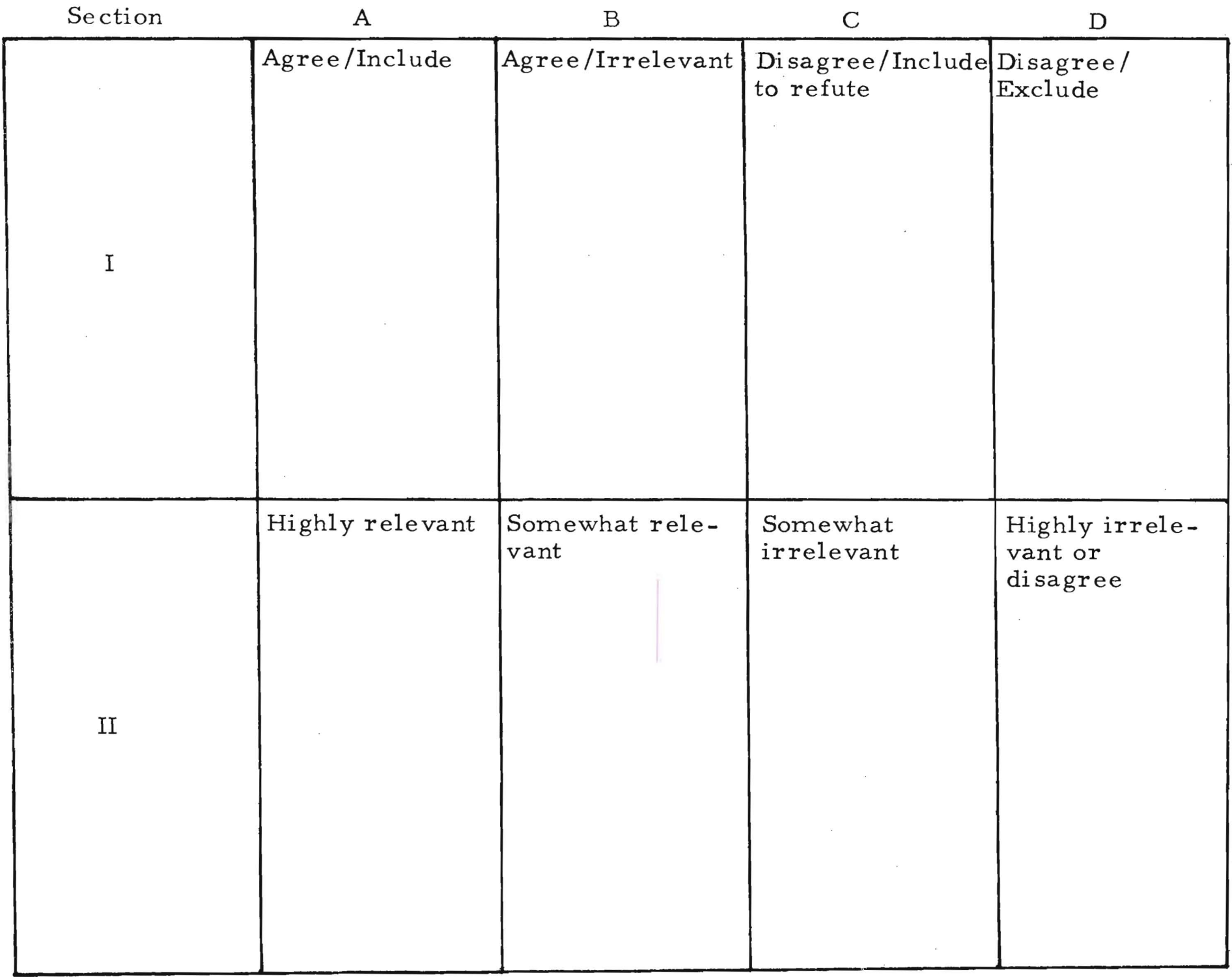




\section{APPENDIX B \\ CATEGORIZATION OF ITEMS}

PAR T I

\section{Paradigm I--Conservative}

1. Teaching poor children to be able to defer need gratification will be essential in helping them to rise out of poverty.

3. The cycle of poverty is difficult to break because the attitudes and feelings of the poor (i.e., fatalism and helplessness) are passed on from generation to generation, causing a vicious circle that can be broken only by highly-motivated individuals.

8. If there were enough mental health facilities and rehabilitation centers to reach all poor and disadvantaged people, our society could deal effectively with the problem of poverty.

13. One factor that works to perpetuate poverty in this country is the general lack of acceptance of or desire for birth control among poor women, resulting in large families that are difficult to support.

\section{Paradigm I--Liberal}

6. Public assistance -gets people used to not having to work for a living and makes it harder to motivate them for future employment.

10. As a nation we need to invest in a massive campaign of education and vocational training for the poor if we are ever going to make a dent in poverty.

12. Encouraging people to move out of "poverty pockets" (i.e., ghettos) so that they are not surrounded by a materially and culturally impoverished environment will help them to break the cycle of poverty in their lives.

15. Improved and more efficient manpower programs for disadvantaged people would bring us closer to solving the problems of poverty. 
Paradigm II--Liberal

4. Lower class people share society's general success goals but lack legitimate opportunities for achieving them; therefore, social workers must encourage the development of more job opportunities.

7. A disproportionate number of minority people are poor in America because of the prejudicial attitudes of many white Americans.

14. The general public isn't very aware of its legal rights, and this prevents many people who are eligible for some kinds of benefits or programs from taking full advantage of these opportunities.

16. Another factor contributing to poverty is that many people who might be eligible for welfare don't apply because of the stigma and dehumanizing treatment involved.

Paradigm II--Radical

2. If our nation had a government-planned economy, wages and salaries would be fairer, jobs more steady, and we would have less unemployment and poverty.

5. Poverty and unemployment will not be eradicated as long as we have a free enterprise economy, for they are necessary for its functioning (by keeping wages down and providing cheap labor).

9. The development of an effective poor people's labor movement would do more to advance the war on poverty than any measure that has been taken by our existing government.

11. A crucial reason this country hasn't been able to solve poverty is because the government's first allegiance is to large corporations who put profits before people. 
PAR T II

DIRECT SER VICE

\section{$\underline{\text { Paradigm I--Conservative }}$}

2. I would focus on Melba's feelings about herself, so we could get to the root of the problems she finds herself in.

6. I would refer Melba to the agency's money-management counselors, who could help her learn to plan for the future and avoid getting behind in her rent.

9. I would help Melba examine the "lifescript" that may be stopping her from getting off welfare, as a starting point for on-going counseling.

12. If Melba were open to counseling beyond the crisis situation, I would focus on her relationships with men in order to help her break the pattern of having illegitimate, unsupported children.

Paradigm I--Liberal

4. I would encourage Melba to get into some kind of vocational training or GED program with the goal that she could eventually get off welfare.

7. I would encourage Melba to take advantage of the WIN program, whereby she could work and still stay on welfare, raising her income considerably.

13. I would encourage Melba to get involved in a single mothers' group, to give her support and to discuss ways of improving their situations.

16. I would suggest to Melba that perhaps enrolling in some courses at the local community college (for which a high school diploma is not required) would give her a chance to learn and do something interesting. 
$\underline{\text { Paradigm II-_Liberal }}$

1. I would refer Melba to the local Welfare Rights organization so that she could learn her rights as a welfare client, to take advantage of opportunities for improving her situation.

8. In acting as Melba's advocate, I would write to the state director of public welfare regarding the financial problems of welfare clients.

10. I would encourage Melba to explore alternatives that may be open to her, that she may not be aware of, such as being eligible for low-cost housing.

14. I would act as Melba's advocate and make sure that her landlord didn't treat her unfairly and that she got courteous, attentive treatment at the welfare department, walking her through the agency if necessary.

$\underline{\text { Paradigm II--Radical }}$

3. I would present to Melba the alternative of participating in a demonstration being planned to protest the inadequacy of welfare payments.

5. I would acknowledge Melba's helpless depression as understandable in her situation and would try to channel it into anger at the social conditions that contribute to her predicament.

11. I would organize a group of social workers and clients with similar problems around the is sue of child care services to take some collective action at the state capitol.

15. I would suggest some critical books on American society and the welfare system for Melba to read, in order to broaden her awareness while, at the same time, improving her reading skills. 
PAR T II

PLANNING

\section{Paradigm I--Conservative}

2. Expanding social services through public welfare to include parent education classes and family therapy would provide a valuable source of support to unstable families, by helping to strengthen family relationships.

7. A law should be enforced whereby welfare mothers who continue to have illegitimate children will be required to undergo sterilization if they want to keep receiving assistance.

13. A program should be developed to remove children from the homes of welfare families who are not able to stay together as a unit, so that the children won't grow up in a highly unstable situation.

16. We should institute a law that imposes an economic sanction on the welfare family if the male head of the household leaves (if he was with the family when they initially applied for aid), as an incentive to keep him in the home.

Paradigm I--Liberal

4. Developing a "Welfare Hotline" service operating on a round-theclock basis could help forestall many family crises by providing immediate counseling and/or advice.

8. I would recommend the allocation of state and federal funds to community social service agencies for the purpose of their developing special programs for welfare families, aimed at promoting and enhancing family stability.

10. I would propose the development of a medical counseling and referral service for welfare clients, since poor people tend to have more health problems than other segments of society, and poor physical health can often affect the emotional climate and stability of relationships within families.

12. I would recommend that efforts be focused on expanding job training programs and increasing training allowances, as a way to enhance potential family stability. 
$\underline{\text { Paradigm II--Liberal }}$

3. I would argue that any attempts to stabilize welfare families were futile unless the payments they received were realistic for economic survival in this day.

5. I would propose developing within the institution a department of "client advocates" who would intervene on behalf of individual clients in any problem situation within the community, thereby reducing stress on families in coping with the environment.

9. I would propose the development of an inter-agency coordinating council, so that the various community agencies providing social services to families could coordinate and balance each other's efforts.

14. I would recommend a campaign to de-stigmatize welfare by such measures as a liberalization of means test procedures and public promotion of the necessity and benefit of public assistance programs.

$\underline{\text { Paradigm II--Radical }}$

1. I would urge the board to lobby in Congress for the abolition of our present welfare system and the adoption of an adequate guaranteed annual income, since the existing system inherently undermines family stability.

6. I would urge the state to recommend to the federal government that it embark on a massive program of reordering its priorities so that human needs were placed at the top of the list.

11. I would advocate the creation of a task force to research the state of the modern family, including all its variations, and the historical development of social stresses that impinge upon family stability and functioning.

15. I would urge the board to look at how factors outside of but related to the welfare system (such as racist practices of hiring and firing) affect family stability. 